\title{
Heterogeneous Freezing of Liquid Suspensions Including Juices and Extracts from Berries and Leaves from Perennial Plants
}

\author{
Laura Felgitsch ${ }^{1, *}$, Magdalena Bichler ${ }^{1}$, Julia Burkart ${ }^{1,2}$, Bianca Fiala ${ }^{1}$, Thomas Häusler ${ }^{1}$, \\ Regina Hitzenberger ${ }^{2}$ and Hinrich Grothe ${ }^{1}$ (D) \\ 1 Institute of Material Chemistry, TU Wien, 1060 Vienna, Austria; Magdalena.bichler@tuwien.ac.at (M.B.); \\ julia.burkart@univie.ac.at (J.B.); bianca.fiala@tuwien.ac.at (B.F.); thomas.haeusler@tuwien.ac.at (T.H.); \\ hinrich.grothe@tuwien.ac.at (H.G.) \\ 2 Faculty of Physics, Aerosol Physics and Environmental Physics, University of Vienna, 1090 Vienna, Austria; \\ regina.hitzenberger@univie.ac.at \\ * Correspondence: laura.felgitsch@tuwien.ac.at
}

Received: 18 December 2018; Accepted: 13 January 2019; Published: 17 January 2019

\begin{abstract}
Heterogeneous ice nucleation in the atmosphere is not fully understood. In particular, our knowledge of biological materials and their atmospheric ice nucleation properties remains scarce. Here, we present the results from systematic investigations of the ice nucleation activity of plant materials using cryo-microscopy. We examined berry juices, frozen berries, as well as extracts of leaves and dried berries of plants native to boreal regions. All of our samples possess reasonable ice nucleation activity. Their ice nucleating particle concentrations per unit of water volume vary between $9.7 \times 10^{5}$ and $9.2 \times 10^{9} \mathrm{~cm}^{-3}$ when examined within temperatures of -12 to $-34^{\circ} \mathrm{C}$. Mean freezing temperatures ranged from -18.5 to $-45.6{ }^{\circ} \mathrm{C}$. We show that all samples contained ice nuclei in a size range below $0.2 \mu \mathrm{m}$ and remain active if separated from coarse plant tissue. The results of examining ice nucleation properties of leaves and dry berry extracts suggests that their ice-nucleating components can be easily suspended in water. Sea buckthorn and black currant were analyzed using subtilisin (a protease) and urea. Results suggest proteinaceous compounds to play an important role in their ice nucleation activity. These results show that separation between ice nucleation particles stemming from microorganisms and those stemming from plants cannot be differentiated solely on proteinaceous features. Further oxidation experiments with ozone showed that black currant is highly stable towards ozone oxidation, indicating a long atmospheric life time.
\end{abstract}

Keywords: biological ice nucleation; heterogeneous ice nucleation; ice-nucleating macromolecules; ice-nucleating particles; cold hardiness

\section{Introduction}

While ice is the thermodynamically favorable phase at temperatures below $0{ }^{\circ} \mathrm{C}$, ice formation is a kinetically hindered process and will typically not take place at higher sub-zero temperatures [1-3]. For small volumes (as droplets in the lower $\mu \mathrm{m}$ size range) this transition occurs at temperatures below $-35{ }^{\circ} \mathrm{C}[4,5]$. If ice nucleation active substances, called ice nucleating particles (INP) [6], initiate freezing at higher (sub-zero) temperatures, the process is referred to as heterogeneous ice nucleation. INP influence cloud glaciation and therefore the water cycle and the radiation balance of the Earth [7-10]. Within the large field of INP, biological INP, which often exhibit the highest onset temperatures (near $0{ }^{\circ} \mathrm{C}$ ) are least understood [11-13]. It is generally assumed that larger particles and especially mineral dust are mainly responsible for atmospheric heterogeneous ice nucleation events $[14,15]$. Possible atmospheric impacts of biological particles have been studied 
using well-established models [16-18]. These models found it unlikely that biological INP play a big role in global INP distributions, but for many calculations, the available data on biological INP needs to be expanded $[16,17]$. Calculations and field studies show however, that local climatic conditions can be highly influenced by biological INP [16,17,19-22]. Many known and strongly studied biological INP stem from microorganisms (as e.g., Pseudomonas syringae, a bacterium [23]). Living organisms pose an even bigger challenge to research, as not just the upward fluxes into the atmosphere must be researched but further questions like viability if airborne, and impacts of the surrounding environment (e.g., pH value) come into play [24,25]. Also, the atmosphere is a highly oxidant medium, which can impact viability and chemical features. The most common oxidant formed in polluted air is ozone [26]. Very little experiments were done in the past to predict the influence of these oxidants on biological INP.

Ice nucleation research is rather complex as environmental features can impact the activity greatly. Furthermore, the mechanisms under which heterogeneous ice nucleation occurs are only poorly understood and differ between different materials. Mineral dusts and soots have variable surfaces and cracks and surface defects seem to be important for their ice nucleation activity (INA) [27]. Other than that, INP from biological sources seem to be mostly proteins and lipoproteins forming aggregates [28]. Therefore, biological INA is more a chemical than a morphological feature. Proteins found to be ice nucleation active often exhibit large beta-sheet areas that simulate the ice structure [29-32].

The knowledge on the atmospheric impact of biological INP is sparse. Some studies indicate that biological material from woodlands could be important for local climatic conditions. Huffman et al. found a burst of biological INP over woodland connected to rain events [22]. Pratt et al. analyzed ice crystal residues collected over Wyoming and found a third of it to be biological material and further that $60 \%$ of the highly abundant mineral dusts to be internally mixed with biological or humic substances [33]. While a third is a rather high ratio for biological material and other studies did not find such high amounts, the importance of organic coatings on inorganic material was confirmed in other studies $[34,35]$. Additional studies that clarify the nature of INP from plants, allowing their atmospheric detection is necessary to predict the atmospheric impact. A deeper understanding of mechanism, environmental presence, and atmospheric impact is important since biological material that triggers ice formation not only influences the albedo of the Earth but also can affect the water cycle and trigger precipitation [36,37].

INA has been found in nearly all kingdoms of life such as e.g., different bacteria [38,39], fungi [40,41] and fungal spores [42,43], moss spores [44], and lichen [45]. Biological particles, which are released in the atmosphere, can cover a wide range of possible substances (e.g., fragments of skin and plants, spores, pollen, proteins) and also over a wide range of sizes (from several nanometre up to the millimetre size range) [46]. However, our knowledge of biological particles in the atmosphere is still rather limited and this topic is often excluded in the fields of air chemistry and climate $[24,46]$. Plants are often not considered as a source of atmospheric INP, even though parts of several plants are already known to be ice nucleation active. The wood of Prunus trees [47], Citrus fruits [48], and winter rye leaves [49] for instance, have already been described as ice nucleation active in literature. Furthermore, pollen of many different plant species have been shown to exhibit ice nucleation activity [50,51]. While Diehl et al. [50] focused on entire pollen grains, Pummer et al. [51] showed that these pollen contain ice nucleation active macromolecules (INM), which are only loosely attached to the pollen grain and can be easily washed off of the surface of the pollen (macromolecules are composed of a higher number than normal molecules and range in their size typically between $10^{-5}$ and $\left.10^{-3} \mathrm{~mm}[52]\right)$. Oils from wood of several species and other naturally emitted terpenes can show INA [53]. Decayed plant leaf litter contains ice nucleation active materials and the concentrations of these materials vary with different environmental conditions [54]. Corresponding freezing temperatures are shown in Table A1. Materials from some of the plant species used in this article have been examined previously: the INA of sea buckthorn berries was found to depend on their region of origin with freezing temperatures ranging from -15.1 to $-6.1^{\circ} \mathrm{C}$, which strongly depend on 
the ripeness of the berries $[55,56]$. The respective INPs can be extracted from the berries but are also accessible from leaf tissue. They remain active if passed through a $0.45 \mu \mathrm{m}$ filter [55], which counts for their macromolecular nature. Proteinaceous compounds are believed to play an important role in the INA of sea buckthorn [55]. Stem, flower bud, fruits, and leaves of Japanese grown examples of Vaccinium corymbosum and Vaccinium ashei (blueberry) were analyzed and found to contain INP [57]. The highest INA of the different blueberry samples was found the bark of the plants [57].

For most plants, the chemical nature of the contained INP is still unknown or remains under discussion. The INP of birch pollen for example has been postulated to depend mostly on polysaccharides [51,58] and on proteins [59]. The chemical nature of these INP needs to be identified in order to find better ways to measure their presence in soil and mineral dusts as well as in atmospheric aerosols and cloud crystal residues.

Most freezing studies done with plants focus on freezing point depression or ice propagation throughout plant tissue (e.g., $[60,61])$. Very little research is done on INA of plants as well as activity of the INP separated from plant tissue and its availability for the surrounding environment. In this study, we systematically investigated the INA of juices and extracts from various berries. We focus on plants from boreal regions to gain a better insight on their freezing behavior and their possible influences on the environment. Our scientific questions include: (1) What is the INA of the selected species? (2) What is the size of the contained INP and can they be compared to the INM found in birch pollen [51,62]? (3) To what extent are there commonalities between the INA of the different analyzed samples? (4) Can the INP be extracted from the intact surface of the plants and therefore impact their local environment?

\section{Experiments}

\subsection{VODCA (Vienna Optical Droplet Crystallization Analyzer)}

The Vienna optical droplet crystallization analyzer (VODCA) works with an emulsion technique allowing us to analyze droplets in the micrometer size range of a sample solution in an inert oil matrix. It was used to determine the ice nucleation activity of our samples. The method is described in detail in Pummer et al. [51]. Here aqueous samples were emulsified in an oil phase (paraffin oil with $10-20 \mathrm{wt} \%$ of lanolin as an emulsifier). A drop of oil and a drop of the aqueous sample (approx. $2 \mu \mathrm{L}$ each with the oil phase in a small excess) are placed on a thin glass slide. For all extracts and blank measurements water of ultrapure grade (produced with Millipore ${ }^{\circledR}$ SAS SIMSV0001, Merck Millipore, Burlington, NJ, USA) was used. The two phases were mixed manually with a pipette tip until the emulsion turned opaque (due to Mie scattering). This method leads to aqueous droplets (between $15-40 \mu \mathrm{m}$ in diameter) embedded in an inert oil matrix [63]. The glass slide was then placed in the cryo-cell. The cryo-cell was sealed and cooled with a Peltier element (Quick-cool QC-31-1.4-3.7M, Quick-cool, Wuppertal, Germany). The temperature of the Peltier element with the glass slide on top was constantly monitored with a thermocouple, which was fixed on the surface of the Peltier element, next to the glass slide. Temperature measurement of our setup exhibited a standard deviation of $0.5{ }^{\circ} \mathrm{C}$ at $-36{ }^{\circ} \mathrm{C}$. Experiments on the pure and filtered juices were done with a cooling rate of approx. $10^{\circ} \mathrm{C} / \mathrm{min}$. Urea and subtilisin treated samples, as well as the ozone treated samples were measured with a cooling rate of approx. $20^{\circ} \mathrm{C} / \mathrm{min}$. We observed the freezing of the droplets via an incident light microscope (Olympus BX51M, Olympus, Shinjuku, Japan) with an attached camera (Hengtech MDC320, 3.2M pixel) linked to a computer. The microscope was equipped with a 20x magnification lens (Olympus LMPlanFL N, Olympus, Shinjuku, Japan). Freezing could be observed via light microscopy due to the change in light scattering behavior when liquid droplets freeze. For each sample, we analyzed in total between 35 and 250 droplets. We reached this aim by using different spots on the emulsion. As the droplet density and size distributions of the different emulsions varied, the evaluated droplet number varied, respectively. All measured droplets of a single sample are combined for evaluation. Theoretically, heterogeneous ice nucleation is independent of the droplet volume 
and depends only on the characteristics of the contained nucleus and its freezing temperature [64]. However, as the concentration of INP is constant, larger droplets in our set-up contain a higher number of INP and therefore more sites on which freezing can occur. This increases freezing temperatures of larger droplets. To minimize resulting inaccuracy, only droplets in the size range of $15-40 \mu \mathrm{m}$ in diameter (droplet volume: $1.8-34 \mathrm{pL}$ ) are included in our evaluation. This size range was chosen as the droplets are small enough to enable us to analyze up to thirty droplets (sometimes even more) per spot, resulting in a sufficient number of analyzed droplets. At the same time they are large enough to be easily evaluated concerning their aggregate state.

At the beginning of the measurement a photo of the sample in liquid form was taken as a reference. Once freezing occurs photos of the sample and the respective temperature $T_{\text {photo }}$ were recorded multiple times during the freezing process. Frozen and unfrozen droplets were counted for each picture. This enabled the determination of the fraction of frozen droplets for every recorded temperature.

\subsection{Data Analysis}

The results are given as mean freezing temperature (MFT) and cumulative nucleus concentration $\left(\mathrm{K}\left(\mathrm{T}_{\text {photo }}\right)\right)$. MFT refers to the weighted average freezing temperature of the sum of all observed droplets per sample described by the equation

$$
\mathrm{MFT}=\frac{\sum\left(T_{i} \times n_{i}\right)}{n_{\text {total }}}
$$

with $T_{i}$ being a recorded temperature, $n_{i}$ being the number of droplets freezing at this temperature, and $n_{\text {total }}$ being the total number of droplets observed during the experiment. This includes droplets freezing homogeneously. For samples with a high fraction of droplets freezing homogeneously and especially also those exhibiting freezing point depression, this can lead to MFT values at or below the freezing temperature of pure water $\left(-36.8^{\circ} \mathrm{C}\right)$.

$\mathrm{K}\left(\mathrm{T}_{\text {photo }}\right)$ indicates the number of INP (or INM) that are ice nucleation active at temperatures at or above $T_{\text {photo }} . \mathrm{K}\left(\mathrm{T}_{\text {photo }}\right)$ is based on the same measurement as the MFT value i.e., counts of the number of frozen droplets $n_{\text {frozen }}$ at the observation temperature $T_{\text {photo }}$. However, $\mathrm{K}\left(\mathrm{T}_{\text {photo }}\right)$ is additionally normalized by the droplet volume $\mathrm{V}$ and, if necessary, a dilution factor $\mathrm{d}$. The diameter of our droplets varied between 15-40 $\mu \mathrm{m}$ with a mean diameter of approx. $25 \mu \mathrm{m}$, which was used for calculations. All samples showing purely heterogeneous freezing were diluted to the point where some droplets were observed to freeze homogeneously (i.e., freezing events occurred at $-36.8^{\circ} \mathrm{C}$ or lower in case of freezing point depression) indicating that these droplets contained no ice nucleation active material. Dilution was necessary (a) to evaluate the cumulative nucleus concentration at lower temperatures (as we cannot evaluate the concentration after 100\% of the droplets were frozen) and (b) to avoid an underestimation of the concentration of INP freezing at lower temperatures than the highest active INP [65]. Dilution prior to the measurement was done for black currant and sea buckthorn juice (J1a,b; $\mathrm{J7a}, \mathrm{b})$ and juniper berry extract (E1).

The cumulative nucleus concentration is described as $[13,64]$

$$
\mathrm{K}\left(\mathrm{T}_{\text {photo }}\right)=-\frac{\ln \left(1-f_{\text {ice }}\right)}{V} * d
$$

with $f_{\text {ice }}$ being the frozen fraction, $V$ the droplet volume, and $d$ the dilution factor.

$$
f_{\text {ice }}=\frac{n_{i}}{n_{\text {total }}}
$$

Here again, $n_{\text {total }}$ is the total number of droplets and $n_{i}$ is the number of frozen droplets at a specific temperature. 


\subsection{Samples}

We investigated eighteen different samples from ten different plants native to boreal regions. All samples stem from plants, which can be classified as perennials, as they typically live more than two years. We addressed several points when choosing our samples. The focus on plants native to boreal regions stems from the observation that INA is a cold hardy mechanism [66], leading to the assumption that these plants will contain INP. Further we tried to pick samples, which are quite common in nature. High occurrence means that these plants provide a huge surface in sum and therefore adds relevance to a possible atmospheric influence. Furthermore, we concentrated on samples that were easily accessible for us. These samples were commercially available juices, frozen berry samples, which we used to produce untreated juices in the lab, as well as dried berries and leaves, which we extracted aqueously. All samples were stored at $-18^{\circ} \mathrm{C}$.

Table 1 gives an overview of the samples and includes also the sample IDs used in this paper. All commercially available juices were of organic quality. They were pasteurized at temperatures around $85{ }^{\circ} \mathrm{C}$ with heating times as short as possible to prevent microbial spoilage. Filtered juice samples were gained by centrifuging (Sartorius 2-16P, Sartorius, Göttingen, Germany) the samples at $3500 \mathrm{rpm}$ (1123 g) for $20 \mathrm{~min}$. The resulting clear liquid was retrieved with a syringe and passed through a $0.2 \mu \mathrm{m}$ syringe filter (VWR cellulose acetate membrane, sterile). To examine the frozen berry samples, we extracted the juices via centrifuging the defrosted berries for $20 \mathrm{~min}$ at $3500 \mathrm{rpm}$ (1123 g). The resulting liquid supernatant was passed through a $0.2 \mu \mathrm{m}$ syringe filter. For production of the dried berry extracts, we immersed dried berries in ultrapure water with $500 \mathrm{mg}$ berries per $\mathrm{mL}$ of water. We left the berries in water for six hours at room temperature, occasionally shaking the vial. After six hours $100-200 \mu \mathrm{L}$ of the supernatant were stored for the later usage as pure extract sample. The rest was centrifuged and filtered similar to the juices to obtain the filtered samples. The leaves were put in vials and water was added. The water was added in a quantity that the leaves were submersed but the petiole was above the waterline. This was done in order to extract INP only from the intact leaf surface. In the case of blueberry, we used $2 \mathrm{~mL}$ of water. The other leaves were bigger. For juniper, raspberry, and sea buckthorn $6 \mathrm{~mL}$ water were used. The rest of the treatment was done similar to the dried berry extracts.

Table 1. An overview of all 18 examined samples.

\begin{tabular}{|c|c|c|c|c|c|c|}
\hline Common Name & $\begin{array}{l}\text { Sample } \\
\text { ID }\end{array}$ & Type & Brand & Genus & $\begin{array}{l}\text { Volume/ } \\
\text { Mass }\end{array}$ & $\begin{array}{l}\text { Lot Number/ } \\
\text { Charge }\end{array}$ \\
\hline Black currant & $\mathrm{J} 1 \mathrm{a}$ & Juice & dm Bio & Ribes & $0.33 \mathrm{~L}$ & 61493 \\
\hline Black currant II & $\mathrm{J} 1 \mathrm{~b}$ & Juice & Alnavit & Ribes & $0.33 \mathrm{~L}$ & $\mathrm{n} / \mathrm{a}$ \\
\hline Blueberry & $\mathrm{J} 2$ & Juice & Alnavit & Vaccinium & $0.33 \mathrm{~L}$ & BL 57408 \\
\hline Chokeberry & $\mathrm{J} 3$ & Juice & Alnavit & Aronia & $0.33 \mathrm{~L}$ & $\mathrm{n} / \mathrm{a}$ \\
\hline Cranberry & $\mathrm{J} 4$ & Juice & Alnavit & Vaccinium & $0.33 \mathrm{~L}$ & $\mathrm{n} / \mathrm{a}$ \\
\hline Lingonberry & $\mathrm{J} 5$ & Juice & Alnavit & Vaccinium & $0.33 \mathrm{~L}$ & HL 56893 \\
\hline Sambuccus & J6 & Juice & Alnavit & Sambuccus & $0.33 \mathrm{~L}$ & $\mathrm{n} / \mathrm{a}$ \\
\hline Sea buckthorn & $\mathrm{J} 7 \mathrm{a}$ & Juice & dm Bio & Hippophae & $0.33 \mathrm{~L}$ & 60857 \\
\hline Sea buckthorn & $\mathrm{J} 7 \mathrm{~b}$ & Juice & Alnavit & Hippophae & $0.33 \mathrm{~L}$ & $\mathrm{n} / \mathrm{a}$ \\
\hline Raspberry & B1 & Frozen berries & Spar Natur*pur & Rubus & $200 \mathrm{~g}$ & L 5017 \\
\hline Rowanberry & B2 & Frozen berries & Obst Oswald & Sorbus & $\mathrm{n} / \mathrm{a}$ & $\mathrm{n} / \mathrm{a}$ \\
\hline Juniper berry & E1 & Extract of dried berries & Sonnentor & Juniperus & $35 \mathrm{~g}$ & ALB14013003F10 \\
\hline Rowanberry & E2 & Extract of dried berries & Paulaner Apotheke & Sorbus & $100 \mathrm{~g}$ & $\mathrm{n} / \mathrm{a}$ \\
\hline Sea buckthorn & E3 & Extract of dried berries & $\mathrm{n} / \mathrm{a}$ & Hippophae & $\mathrm{n} / \mathrm{a}$ & $\mathrm{n} / \mathrm{a}$ \\
\hline Blueberry & L1 & Extracts of leaves & Collected in Upper Austria & Vaccinium & - & - \\
\hline Juniper & $\mathrm{L} 2$ & Extracts of leaves & Collected in Upper Austria & Juniperus & - & - \\
\hline Raspberry & L3 & Extracts of leaves & Collected in Upper Austria & Rubus & - & - \\
\hline Sea buckthorn & L4 & Extracts of leaves & Collected in Upper Austria & Hippophae & - & - \\
\hline
\end{tabular}


Birch pollen washing water, which we used as a reference material, was prepared using $50 \mathrm{mg}$ pollen (commercially available Betula pendula pollen from Allergon AB, Ängelholm, Sweden) and adding $1 \mathrm{~mL}$ of ultrapure water. Over a time of six hours it was shaken two to four times. The suspension was then centrifuged for $10 \mathrm{~min}$ with the same settings as the other samples and was filtered with a $0.2 \mu \mathrm{m}$ syringe filter.

Filtration with a size cutoff of $0.2 \mu \mathrm{m}$ removes a vast majority of possible impurities as bacteria and fungi but also other foreign particles, which could be present in the sample. Furthermore, it helps to distinguish between the INA of particulate substances and the INA of macromolecules [62].

\subsection{Urea and Subtilisin Treatement}

To examine the effect of proteins on the INA of black currant (J1a) and sea buckthorn juice (J7a), we used subtilisin and urea. Black currant exhibited the highest INA of all samples, which were not prior known to be active. Sea buckthorn has already been indicated to contain proteinaceous INP in literature [55]. Therefore we chose these two samples for the analysis. Subtilisin is a protease from the bacterium Bacillus licheniformis and as such selectively destroys proteins via hydrolyzing peptide bonds using a catalytic triad [67]. Urea on the other hand is a chaotropic agent, inactivating proteins by denaturation, which can work over direct mechanisms, but also over the disruption of hydrogen bonding networks [68,69]. Subtilisin was chosen as protease as it is more stable towards urea as other proteases, with approx. $10 \%$ activity left using our urea concentrations [70]. The subtilisin and urea tests allow conclusions on the role of proteins in the INA of the tested fruits, and the importance of structural integrity of the INP. As a positive test we used Snomax ${ }^{\circledR}$ suspended in water. Snomax ${ }^{\circledR}$ consists of shredded Pseudomonas syringae membrane. The ice nucleation active compound of Pseudomonas syringae is a membrane protein [39] and therefore it should be affected by the used techniques.

Each sample was treated with urea alone, with subtilisin alone and with urea and subtilisin in combination. An overview of the sample preparation is given in Table 2. Subtilisin (Sigma-Aldrich P5380-25mg, Sigma-Aldrich, St. Louis, MO, USA) was dissolved in tris buffer (0.1 M tris(hydroxymethyl)aminomethane (Sigma-Aldrich 252859-100g) adjusted to a $\mathrm{pH}$ of 8 using $2 \mathrm{M}$ hydrochloric acid) with a concentration of $2 \mathrm{mg}$ subtilisin / $\mathrm{mL}$ buffer. For each experiment, $500 \mu \mathrm{L}$ of the two juices were dried over silica gel in a sterile Petri dish. The residues were dissolved in $1 \mathrm{~mL}$ of ultrapure water for the pure subtilisin treatment or in $8 \mathrm{M}$ urea solution for the urea and the urea and subtilisin treatment. For the pure subtilisin and the combination treatment $100 \mu \mathrm{L}$ of the subtilisin solution were added. In case of the pure urea treatment we added $100 \mu \mathrm{L}$ tris buffer (to account for the tris buffer contained in the samples treated with subtilisin). The addition of the tris buffer or subtilisin solution leads to a urea concentration of $7.3 \mathrm{M}$.

Table 2. Sample preparation for the subtilisin and urea treatments. J1a (black currant juice) and J7a (sea buckthorn juice) refers to the dried residue of $500 \mu \mathrm{L}$ of pure juice.

\begin{tabular}{lccllll}
\hline Treatment & J1a & J7a & $\begin{array}{l}\text { Ultrapure } \\
\text { Water }\end{array}$ & Urea (8 M) & $\begin{array}{l}\text { Tris } \\
\text { Buffer }\end{array}$ & $\begin{array}{l}\text { Subtilisin in Tris } \\
\text { Buffer (2 mg/mL) }\end{array}$ \\
\hline Subtilisin & $\mathrm{X}$ & & $1 \mathrm{~mL}$ & $100 \mu \mathrm{L}$ \\
\hline Subtilisin & & $\mathrm{X}$ & $1 \mathrm{~mL}$ & & $100 \mu \mathrm{L}$ \\
\hline Urea & $\mathrm{X}$ & & & $1 \mathrm{~mL}$ & $100 \mu \mathrm{L}$ \\
\hline Urea & & $\mathrm{X}$ & & $1 \mathrm{~mL}$ & $100 \mu \mathrm{L}$ \\
\hline Urea and Subtilisin & $\mathrm{X}$ & & & $1 \mathrm{~mL}$ & $100 \mu \mathrm{L}$ \\
\hline Urea and Subtilisin & & $\mathrm{X}$ & & $1 \mathrm{~mL}$ & $100 \mu \mathrm{L}$ \\
\hline
\end{tabular}

The prepared samples were stored in a heating and shaking device (Gesellschaft für Labortechnik (GFL) 1086, GFL Gesellschaft für Labortechnik mbH, Burgwedel, Germany) and kept there at $60^{\circ} \mathrm{C}$ 
for $24 \mathrm{~h}$. One sample was drawn from the solutions prior to putting them in the heating and shaking device, another sample was drawn after $1 \mathrm{~h}$. All samples were diluted 10 fold with ultrapure water after extraction from the shaker to reduce the high concentrations of small soluble compounds (especially in case of the urea samples), which otherwise interfere with our measurements due to freezing point depression.

\subsection{Ozone Treatment}

To simulate high oxidative stress on the INP contained in black currant juice (J1b), we used ozone, which is abundant in the atmosphere. Black currant juice exhibited the highest INA of all measured juices, which were not prior known to be active. Therefore it was used for analysis. The ozone treatment was done with a Fischer Ozone Generator 500 (Fischer America Inc., Auburn Hills, MI, USA), with a gas flow of 1-10 mL/s producing approx. $5 \mathrm{~g}$ ozone/ $\mathrm{h}$. The gas outlet of the ozonizer was connected to a washing flask, which was mounted to a magnetic stirrer. The flask contained $35 \mathrm{~mL}$ of the black currant juice, which was constantly stirred, while the ozone was passed through the liquid. The treatment was done for $12 \mathrm{~h}$. A schematic depiction of the setup is given in Figure 1.

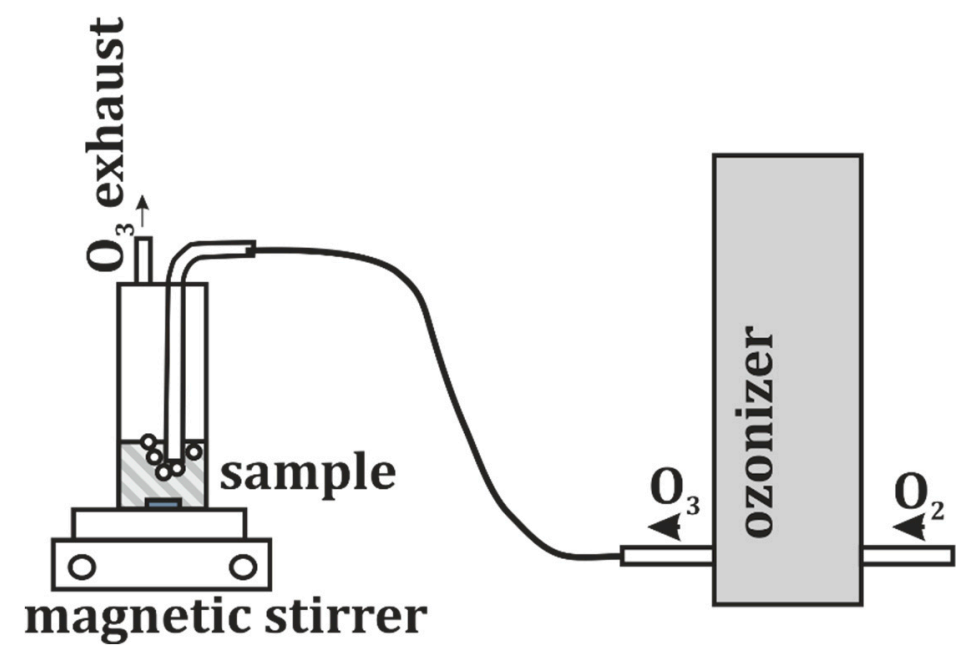

Figure 1. Schematic of the ozone treatment setup. On the right side is an ozonizer, with gas in- and outlet. The outlet is connected to a washing flask containing the sample, which is mounted on a magnetic stirrer.

\section{Results}

\subsection{Unfiltered Samples}

To compare the freezing behavior of the different plant materials we first determined the onset temperature, the mean freezing temperature (MFT) and the cumulative nucleus concentration $\left(\mathrm{K}\left(\mathrm{T}_{\text {photo }}\right)\right)$ of the pure plant materials. The results are plotted in Figure 2 (onset temperature, MFT and $\left.\mathrm{K}\left(-34^{\circ} \mathrm{C}\right)\right)$ and Figure $3\left(\mathrm{~K}\left(\mathrm{~T}_{\text {photo }}\right)\right.$ over the whole temperature range $)$. As comparison material, we introduced aqueous birch pollen washing water (Betula pendula, $-17.1^{\circ} \mathrm{C}$ ), measured with our setup, and juniper pollen washing water (Juniperus communis) extracted from Pummer et al. ([51] $\left.-21.4^{\circ} \mathrm{C}\right)$. Furthermore, we included the MFT of ultrapure water $\left(-36.8^{\circ} \mathrm{C}\right)$ as determined through several measurements over the whole measurement period.

We found INP active at $-34{ }^{\circ} \mathrm{C}$ and higher in all analyzed samples. At this temperature we do not observe any homogeneous freezing events with our setup. We therefore conclude that freezing events of $-34^{\circ} \mathrm{C}$ and higher are purely heterogeneous and are triggered by contained INP. The mean freezing temperatures of the unfiltered juices range from $-18.5^{\circ} \mathrm{C}$ (sea buckthorn J7b) to $-36.5^{\circ} \mathrm{C}$ (blueberry J2). MFT of unfiltered extracts ranged from $-24.3^{\circ} \mathrm{C}$ (juniper berries E1) to $-38.1^{\circ} \mathrm{C}$ (rowanberries E2). Freezing temperatures of the extracts of leaves ranged from $-30.0^{\circ} \mathrm{C}$ (L2, juniper) to $-35.6^{\circ} \mathrm{C}$ 
(L4, sea buckthorn). The majority of unfiltered samples exhibited onset temperatures above $-25^{\circ} \mathrm{C}$, except for J2 $\left(-25.2{ }^{\circ} \mathrm{C}\right.$ onset temperature) and E2 $\left(-29.4{ }^{\circ} \mathrm{C}\right.$ onset temperature).

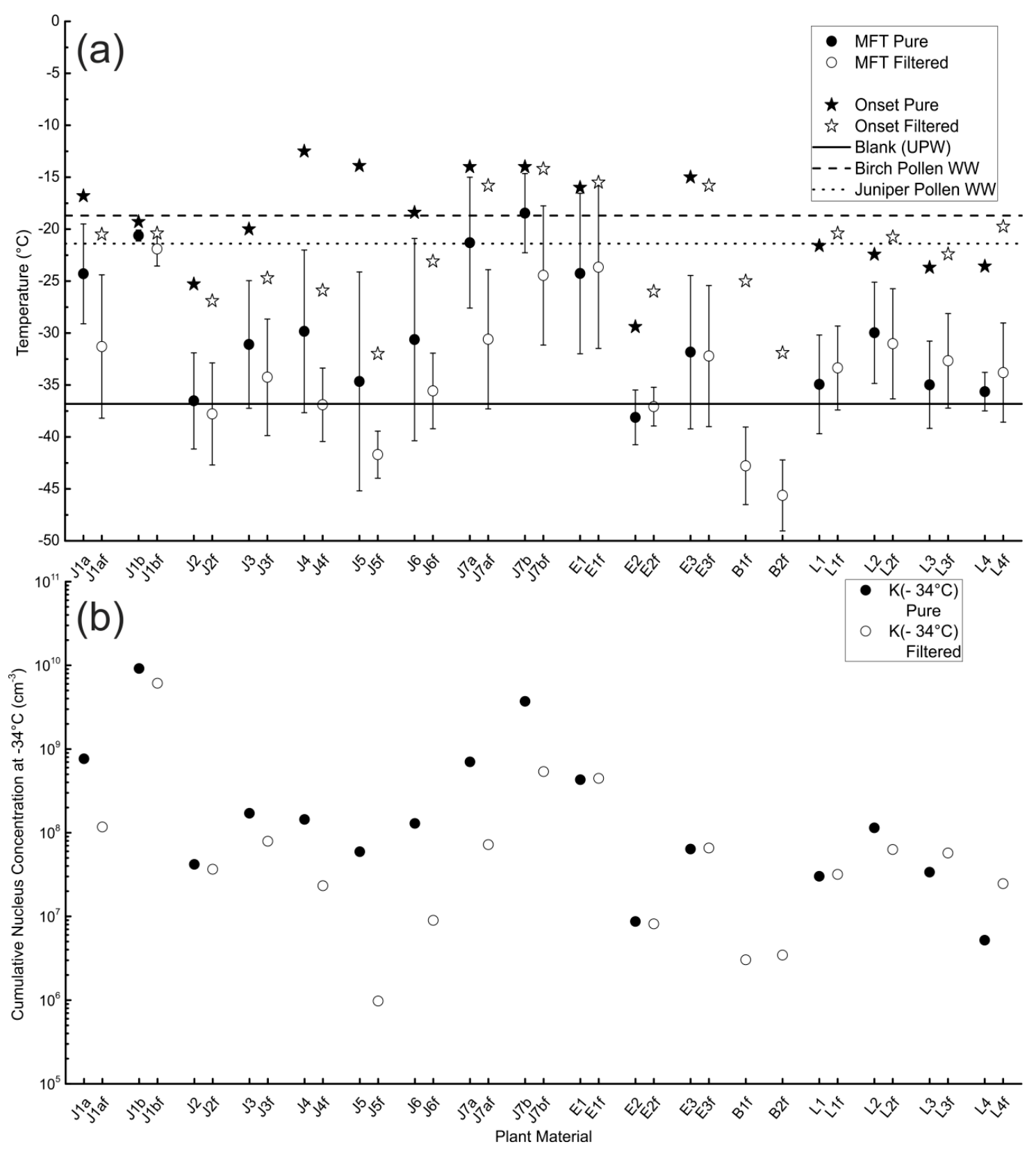

Figure 2. (a): MFT (circles) and onset temperature (stars) of the analyzed juices (black currant (J1), blueberry (J2), chokeberry (J3), cranberry (J4), lingonberry (J5), sambuccus (J6), sea buckthorn (J7)), dried berry extracts (juniper berries (E1), rowanberries (E2), sea buckthorn (E3)), frozen berries (blueberry (B1) and Raspberry (B2)) and leaf extracts ((L1) blueberry, (L2) juniper, (L3) raspberry, (L4) sea buckthorn). Samples marked with an $\mathrm{f}$ are filtered (particles $<0.2 \mu \mathrm{m}$ in diameter) and are displayed as hollow symbols; filled symbols correspond to unfiltered samples. MFTs are given with the respective standard deviation as error bar. The graph contains three lines: the dashed line refers to the mean freezing temperature of birch pollen washing water $\left(-18.7^{\circ} \mathrm{C}\right)$, the dotted line to juniper pollen washing water $\left(-21.4^{\circ} \mathrm{C}\right.$, extracted from Pummer et al. [51]), and the solid line refers to the MFT of ultrapure water (UPW) measured with our setup during the measurement series $\left(-36.8^{\circ} \mathrm{C}\right)$. (b): The cumulative nucleus concentration at $-34^{\circ} \mathrm{C}\left(\mathrm{K}\left(-34^{\circ} \mathrm{C}\right)\right)$. Again, filtered samples are marked with an $\mathrm{f}$ and hollow symbols, while unfiltered samples are represented by filled symbols. 

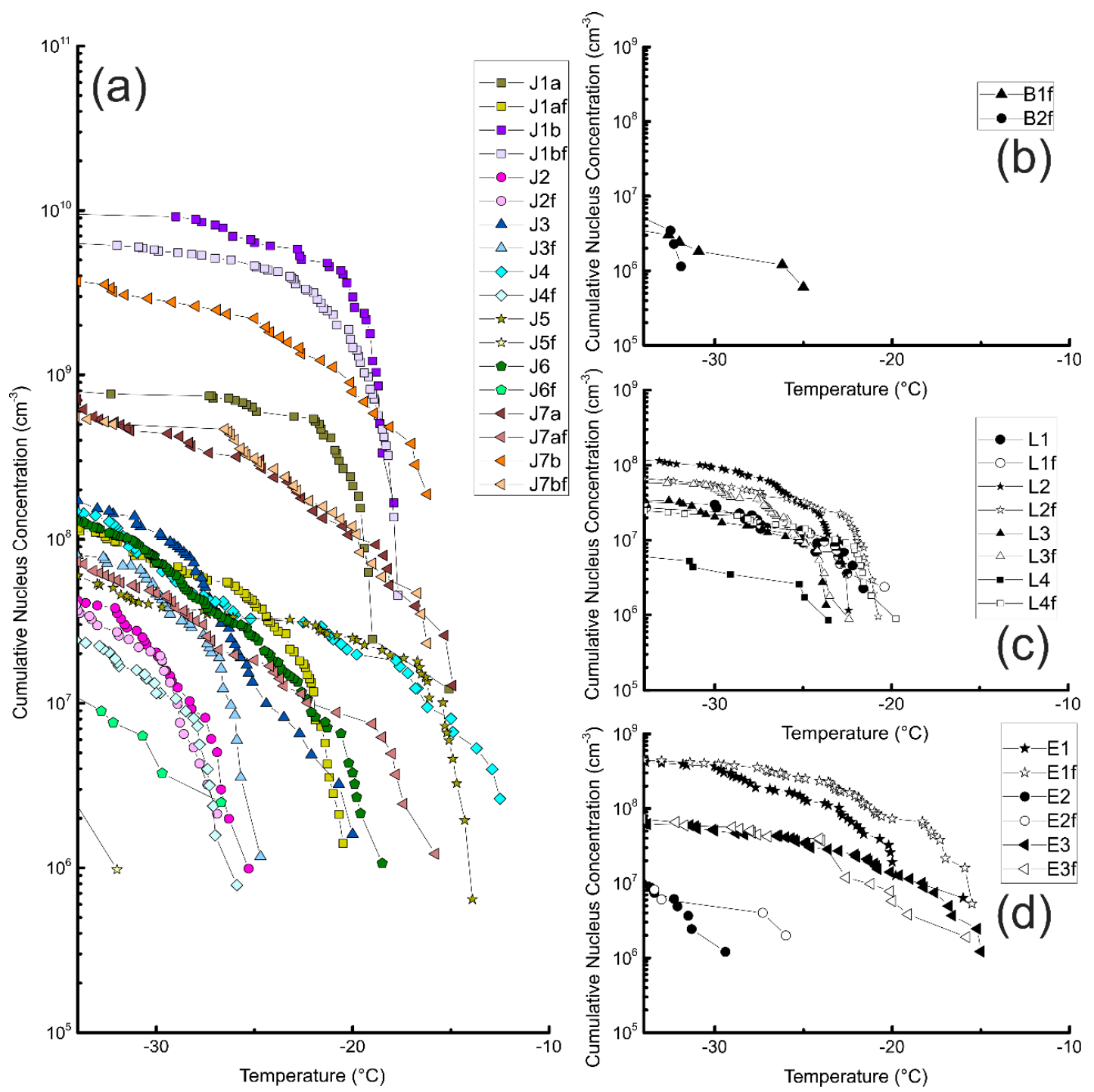

Figure 3. (a) $\mathrm{K}\left(\mathrm{T}_{\text {photo }}\right)$ of the analyzed samples. Juices (black currant (J1a,b), blueberry (J2), chokeberry (J3), cranberry (J4), lingonberry (J5), sambuccus (J6) sea buckthorn (J7a,b)); (b) extracts of leaves (blueberry (L1), juniper (L2), raspberry (L3), and sea buckthorn (L4)); (c) extracts of leaves (blueberry (L1), juniper (L2), raspberry (L3), and sea buckthorn (L4)); (d) extracts of dried berries (juniper berries (E1), rowanberries (E2), sea buckthorn (E3)). Samples marked with an $\mathrm{f}$ are filtered and do not contain particles bigger $0.2 \mu \mathrm{m}$. Data points at temperatures below $-35^{\circ} \mathrm{C}$ are not represented, since we cannot exclude homogeneous nucleation events at lower temperatures and therefore cannot attribute those data points to INM with full certainty.

Figure 2 includes birch pollen and juniper pollen washing water as comparison standards. Birch pollen washing water was chosen as it is a well-established INP from plants [50,51]. Juniper pollen were chosen since we have two juniper samples within our sample groups (L2 juniper, E1 juniper berries). While mean freezing temperatures are mostly below these two comparison lines, the onset temperatures of most samples are between or above these lines, except for the leaves, which were all slightly below these two lines.

The MFT of unfiltered blueberry juice (J2) lies close to the homogeneous freezing line (see Figure 2) of ultrapure water $\left(-36.8^{\circ} \mathrm{C}\right.$, as determined with regular measurements with our setup during the measurement series), the MFT of unfiltered rowanberry extract (E2) even below. This can be explained by a low concentration of INP in the samples. Further ions and small sugars in our sample lead to freezing point depression, broadening the range of freezing events down to temperatures below the 
freezing point of ultrapure water. However, we found heterogeneous freezing events in all analyzed samples, which is indicated by the $\mathrm{K}\left(\mathrm{T}_{\text {photo }}\right)$ (see Figures 2 and 3 ) and the onset temperature (see Figure 2). The $\mathrm{K}\left(-34^{\circ} \mathrm{C}\right)$ values followed the trend of the MFT (see Figure 3). This shows again that the MFT reflects the concentration of INP.

We further looked at the role of the dry mass on the number of contained INP in unfiltered juices. Dry mass refers to the weight of residues of dried samples, given in $\mathrm{mg} / \mathrm{mL}$ (dry mass $/ \mathrm{mL}$ sample dried) and it varied strongly between the different samples. To investigate if differences in the INP concentrations are related to differences in the dry mass concentrations, we plotted different mass concentrations of all nine unfiltered juice samples against the number of INP active at or above $-34{ }^{\circ} \mathrm{C}$ (see Figure 4). There is no correlation between dry mass and INP content (a linear fit yields an $\mathrm{R}^{2}$ value of 0.0124; not shown). This means that the concertation of INP is not a function of the dry mass of the sample, i.e., different plants contain different amounts of INP.

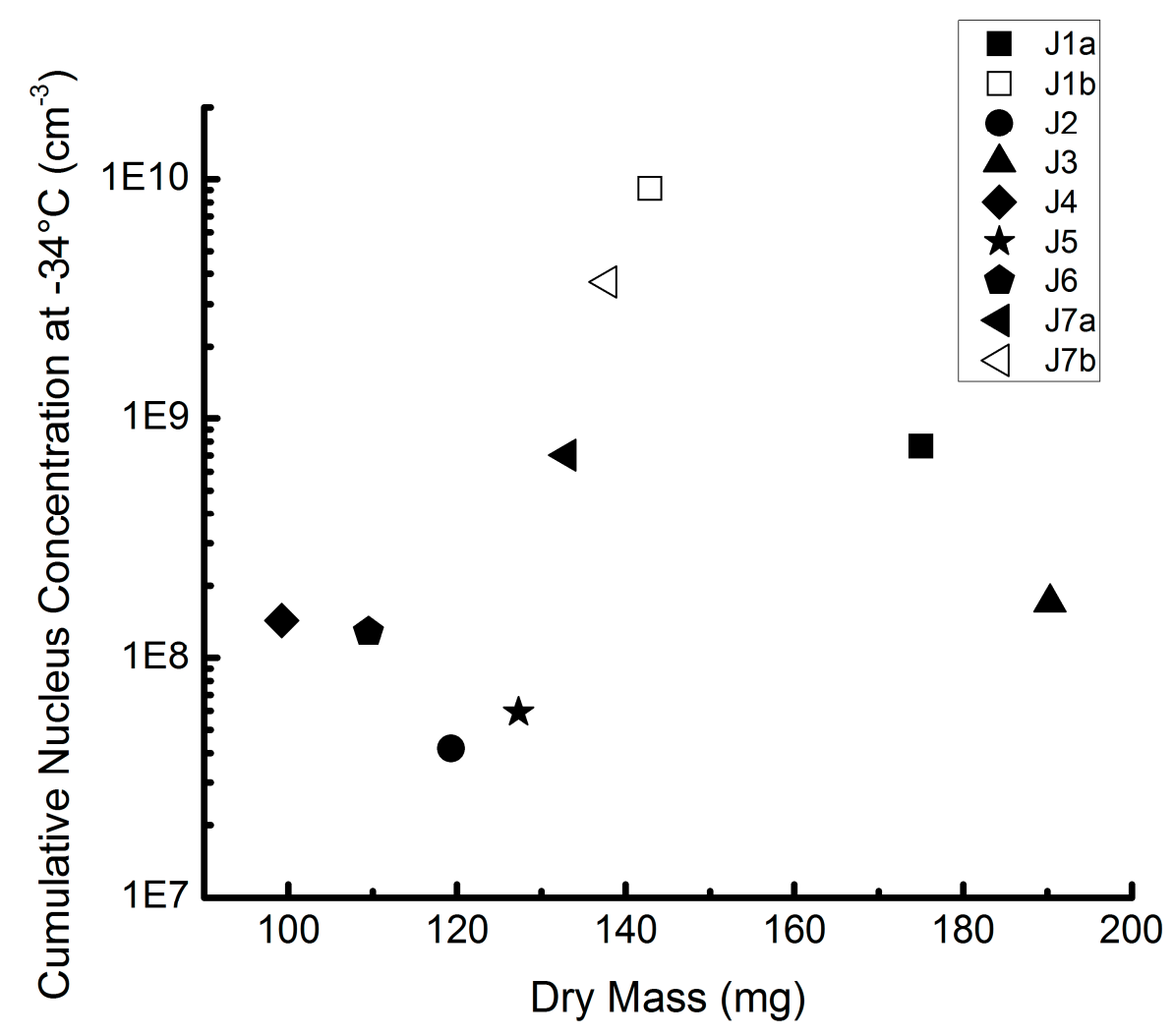

Figure 4. Relationship between the INP concentration of the juice samples and their dry mass. Included juices were black currant (J1a,b), blueberry (J2), chokeberry (J3), cranberry (J4), lingonberry (J5), sambuccus (J6), sea buckthorn (J7a,b). Linear regression (not shown) yields an $\mathrm{R}^{2}$ value of 0.0124 .

\subsection{Filtered Samples}

In a second step we investigated the freezing behavior of the filtered juice and extract samples. The cumulative nucleus concentration and the freezing temperature of the filtered juices decreased in all cases with varying intensities. However, even after filtration all samples still showed INA. We found the highest loss of INP represented by the $\mathrm{K}\left(-34^{\circ} \mathrm{C}\right)$ for lingonberry juice (J5, approx. $98 \%$ ) and the smallest for blueberry juice (J2, approx. 13\%). Black currant juice (J1b), the sample with the highest concentration of INP lost a third of its INP due to filtration. In contrast to the filtered juices, the extracts showed no loss of INP due to filtration, demonstrating that the extracts did not contain INP larger than $0.2 \mu \mathrm{m}$. For the extracts of berries and leaves we see no major losses. In all cases the mean freezing temperatures stayed within the standard deviation of each other. Only for L4 we see not a decrease but an increase for the filtered sample. Since the production of the frozen berry samples 
included centrifugation, we had no sample containing bigger suspended material. We only measured filtered samples of this group and are not able to compare their freezing behavior to unfiltered samples. The filtered frozen berry samples exhibited the lowest MFT of all samples and very low cumulative nucleus concentrations with only filtered lingonberry juice (J5f) exhibiting lower concentrations.

Overall, all filtered samples contained INP with varying concentrations. We assume these INP to be INM. Six of the analyzed eighteen filtered samples exhibited MFT at or below the homogeneous freezing line $\left(-36.8^{\circ} \mathrm{C}\right)$. Those samples were blueberry juice (J2f), lingonberry juice (J4f), sambuccus juice (J5f), rowanberry extract (E2f), frozen raspberries (B1f), and frozen rowanberries (B2f). The $\mathrm{K}\left(-34^{\circ} \mathrm{C}\right)$ values followed the same trend, indicating again that low MFT values are an effect of low INM concentrations. For the rest of the samples, MFT values varied between $-21.9^{\circ} \mathrm{C}$ (J1bf, black currant) and $-35.6^{\circ} \mathrm{C}$ (J6f, sambuccus). Onset temperatures ranged between $-14.2^{\circ} \mathrm{C}$ (J7bf, sea buckthorn) and $-31.9^{\circ} \mathrm{C}$ (B2f, rowanberry).

\subsection{Comparison of Different Samples and Sample Classes}

We analyzed two different black currant juices (J1a and J1b), with J1a showing a reduced INP concentration, as well as reduced onset temperature and MFT. Sea buckthorn, of which four samples (two juices (J7a and b) and aqueous extracts of the dried berries (E3) and of leaves (L4)) were analyzed, behaved similarly. While the freezing temperature of the black currant as well as the sea buckthorn juices varied (see Figure 2), the curve progression of their cumulative nucleus concentration against temperature plots are similar, but shifted in their concentration (see Figure 3). This indicates that in different analyzed samples of a species for both cases, same or similar INP are present, however, in varying concentration. Interestingly, filtration impacted the two chosen juices differently in both cases. The juices marked with an $a$ showed a higher loss in INP concentration than the juices marked with a $b$.

In case of sea buckthorn, the extracts of dried berries show similarities to the juice, while the leaves exhibit not just lower concentration, but also lack freezing events at temperatures above $-20^{\circ} \mathrm{C}$.

We analyzed rowanberries as extract of dried berries and as frozen berries. In both cases rowanberries exhibited low freezing temperatures and INP concentrations.

Juniper was tested as extract of leaves (L2) and of dried berries (E1). While the curve progressions in Figure 3 are rather similar for temperatures below $-20^{\circ} \mathrm{C}$, the leaves lack the portion of the curve above $-20^{\circ} \mathrm{C}$, which also explains the decreased freezing temperature for the leaves. While the mean freezing temperature of all juniper samples are below the juniper pollen line, the extracts of berries exhibit higher onset temperatures and the extracts of leaves exhibit onset temperatures close to the juniper line.

Raspberry was tested as frozen berries (B1) and as leaf extract (L3). The curve progressions in Figure 3 are similar, with higher concentrations for the leaf extracts.

In the case of blueberry we can compare the results from leaves (L1) to juices (J2). Leaves exhibit activity at higher temperatures than the juice (see Figure 3), even though the concentrations are similar (see Figure 2).

Rowanberries were analyzed as frozen berries (B2) and as aqueous extract of dried berries (E2). For rowanberries the INP concentrations of the different samples matched well, but the frozen berries showed a significantly lower MFT (see Figure 2). We again observed the same progression for the different $\mathrm{K}\left(\mathrm{T}_{\text {photo }}\right)$ curves (see Figure 3$)$.

A closer look at Figures 2 and 3 reveals that the different samples can be divided into four categories with respect to their onset temperatures (the temperature where the first droplets freeze). The first group contains the most potent INP with onset temperatures around $-15^{\circ} \mathrm{C}$ : black currant juice (except for filtered J1af, J1a, J1b, J1bf), cranberry juice (only untreated; J4), lingonberry juice (only untreated; J5), and sea buckthorn juice (filtered and untreated; J7a, J7af, J7b, J7bf), as well as pure and filtered extracts of dried juniper berries (E1 and E1f) and sea buckthorn (E3 and E3f). Furthermore, we can identify a second group with onset temperatures around $-20^{\circ} \mathrm{C}$ (unfiltered sambuccus and chokeberry juice (J6 and J3) as well as all leaf extracts and filtered black currant juice J1af), and the 
third group with onset temperatures at $-25^{\circ} \mathrm{C}$ (filtered sambuccus, cranberry and chokeberry juice (J6f, J4f, and J3f) as well as filtered and untreated blueberry juice (J2and J2f) and frozen raspberries (B1). Filtered lingonberry juice (J5f), the frozen rowanberry sample (B2), as well as the rowanberry extracts (E2 and E2f) show the lowest onset temperatures at approx. $-30{ }^{\circ} \mathrm{C}$. It should be noted that the unfiltered cranberry, lingonberry, and sambuccus juice (J3, J4, and J6) all showed a stepwise curve progression. Interestingly, the second step of the curve occurs at the same temperature as the onset temperature of the corresponding filtered samples, which suggests that filtering leads to the loss of the INP with the higher potency.

\subsection{Urea and Subtilisin Treatment}

To test the effect of our used methods on proteinaceous INP, we used Snomax ${ }^{\circledR}$, which consists of shredded Pseudomonas syringae. The INA of the bacterium is based on membrane proteins [39]. The results are presented in Figure 5. The protease subtilisin reduced the INA of Pseudomonas syringae by nearly $80 \%$ within the $24 \mathrm{~h}$ (see Figure $5 \mathrm{~g}$ ). Urea had an even more drastic effect. The $0 \mathrm{~h}$ sample, which was diluted directly after the urea solution was added left urea only a couple of seconds to react. Already, we see a drastic loss in the $0 \mathrm{~h}$ fraction compared to subtilisin (see Figure $5 \mathrm{~g}, \mathrm{~h}, \mathrm{i}$ ). Due to the strong effect of urea on the sample, we cannot evaluate if subtilisin had an effect when applied in combination with urea.

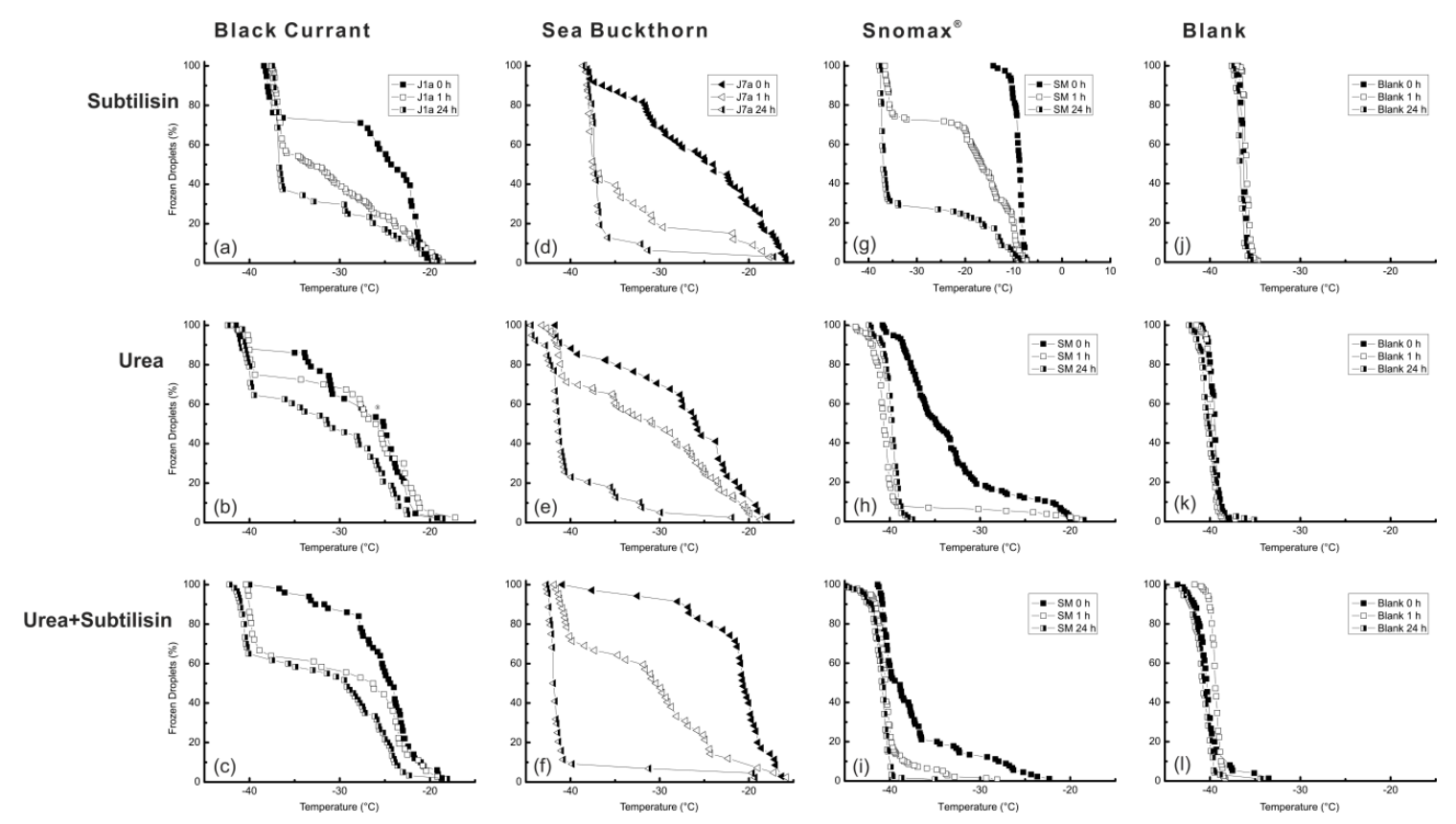

Figure 5. Results of the urea and subtilisin treatments from left to right of black currant juice ((J1a) $(\mathbf{a}-\mathbf{c}))$, sea buckthorn juice $(\mathrm{J} 7 \mathrm{a}(\mathbf{d}-\mathbf{f}))$, Snomax ${ }^{\circledR}(\mathrm{SM}(\mathbf{g}-\mathbf{i}))$, and the blanks (blank $\left.(\mathbf{j}-\mathbf{l})\right)$ shown as fraction of frozen droplets in relation to the temperature. Filled symbols correspond to the sample solutions prior treatment, hollow symbols to the sample after $1 \mathrm{~h}$ of treatment in a shaker at $60{ }^{\circ} \mathrm{C}$, and half-filled symbols to the sample after $24 \mathrm{~h}$ of treatment. The treatment with subtilisin are shown in the top row $(\mathbf{a}, \mathbf{d}, \mathbf{g}, \mathbf{j})$, the treatment with urea are shown in the middle row $(\mathbf{b}, \mathbf{e}, \mathbf{h}, \mathbf{k})$, and the treatment with urea and subtilisin is shown in the bottom row $(\mathbf{c}, \mathbf{f}, \mathbf{i}, \mathbf{l})$. All depicted samples were diluted 10 fold with ultrapure water prior to measurement.

Black currant (J1a) and sea buckthorn juice (J7a) were treated with urea, subtilisin, and a combination of both reagents, to get information on the importance of proteins and their structural integrity on the INA of those juices. Figure 5 shows the effects of the three different treatment methods (see Table 2) on black currant juice (J1a) and sea buckthorn juice (J7a). Both juices were highly affected by subtilisin alone and lost the majority of their activity (Figure 5a,d). In the case of black currant (J1a) 
the INA was halved after $24 \mathrm{~h}$ of treatment (Figure 5a). For sea buckthorn (J7a) we found an even stronger decrease with less than $20 \%$ of droplets containing INP after $24 \mathrm{~h}$ of treatment (Figure $5 \mathrm{~d}$ ). Urea had a less drastic effect on black currant (J1a) than the subtilisin treatment. Approx. $90 \%$ of the droplets analyzed from the untreated sample froze heterogeneously. After $24 \mathrm{~h}$ of treatment with urea alone at $60{ }^{\circ} \mathrm{C}$ still more than $60 \%$ heterogeneously freezing droplets remained (see Figure $5 \mathrm{~b}$ ). Sea buckthorn (J7a) on the other hand again lost the majority of its INA, with approx. $20 \%$ of droplets freezing heterogeneously after $24 \mathrm{~h}$ of treatment (see Figure 5e). When urea and subtilisin are used together, the effect on black currant (J1a) is drastically smaller than when treated with subtilisin alone (see Figure $5 \mathrm{c}$ ). The resulting curve after $24 \mathrm{~h}$ is comparable to the one obtained when black currant is treated with urea alone, only the initial loss (after $1 \mathrm{~h}$ ) is higher in the presence of subtilisin. Sea buckthorn (J7a), which was more strongly affected by urea than black currant (J1a), nearly lost all of its INA after $24 \mathrm{~h}$ of treatment (see Figure $5 \mathrm{f}$ ). After $1 \mathrm{~h}$ and after $24 \mathrm{~h}$, the activity of the urea and subtilisin treated sea buckthorn is slightly lower than the activity of the sea buckthorn sample treated with urea alone.

The last row in Figure 5 are subtilisin, urea, as well as urea and subtilisin solutions without a present sample. We see no heterogeneous freezing in these blanks.

\subsection{Ozone Treatment}

Black currant juice was treated with $1-10 \mathrm{~mL} / \mathrm{s}$ of air containing approx. $0.01 \%$ ozone for $12 \mathrm{~h}$. Ozone is a strong gas phase oxidizer, which is prone to test for the robustness of the INP against oxidation. Therefore the results of this test give an idea on the stability of black currant juice (J1b) towards atmospheric oxidation. The results of the ozone treatment are shown in Figure 6 represented as mean freezing temperatures. We found no significant change in the freezing temperature in the $12 \mathrm{~h}$ of treatment, indicating that the INA of black currant juice is not affected by ozone. The juice however did lose all of its color during the oxidation process.

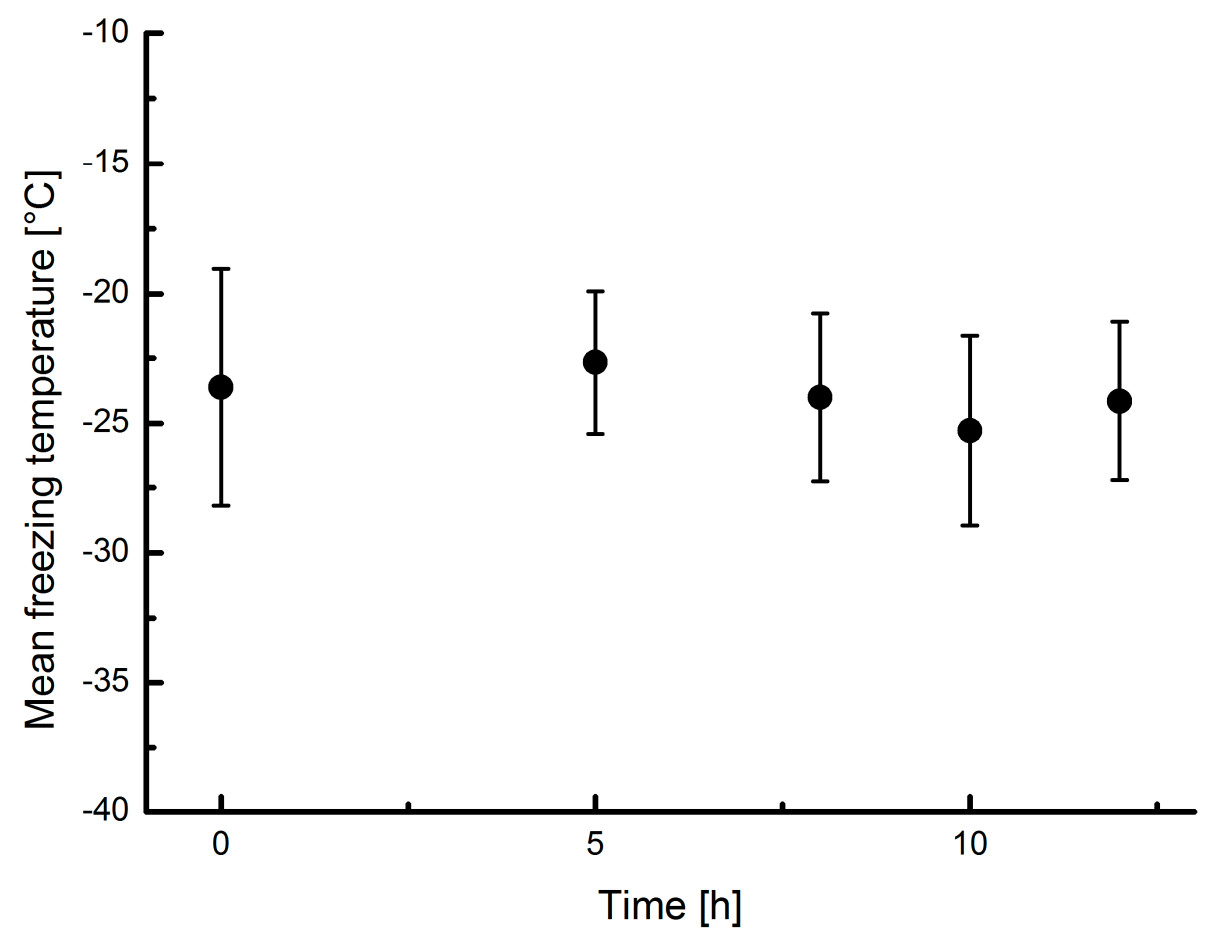

Figure 6. Relation between mean freezing temperature and ozone treatment time of black currant juice $(\mathrm{J} 1 \mathrm{~b})$. 


\section{Discussion}

Since the transport mechanisms of biological materials into the atmosphere are not well corroborated, more detailed studies of plant based INP are of great importance. As of now, we are not able to predict the exact influence those INP could have on atmospheric processes. Our lack of knowledge on number and chemical nature of these INP makes it hard to estimate atmospheric concentrations and to measure their presence in atmospheric samples. With this study, we aim to contribute not just to the knowledge on plant based INP but also to the awareness that plants can be a huge source for INP. The most important finding is the ice nucleation activity of the plant derived material. Every single material we analyzed contained INP active above $-34{ }^{\circ} \mathrm{C}$. More importantly, this was still true if samples were filtered. Filtered samples are not just important as small INP have a higher atmospheric lifespan, but also as the filtering step removes several possible impurities, including but not limited to bacteria. These findings render the presented plants a possibly important source for atmospheric INP. Interestingly, we found differences between the different samples. This is probably seen best when comparing the impact of subtilisin and urea on black currant and sea buckthorn. In both cases, sea buckthorn was impacted stronger than black currant. This leads to the assumption that while proteins affect the INP in both cases, the INA of sea buckthorn is either dependent more strongly on proteins, or the involved proteins are less stable.

All analyzed plant materials (see Table 1) contained INP that were active at or above $-34{ }^{\circ} \mathrm{C}$. Furthermore, we found that the samples still contained INP even if centrifuged and filtered with a $0.2 \mu \mathrm{m}$ size cut-off. However, even though INA remained in all samples, we found a loss for most juices due to filtration. This indicates that at least a part of the INP in juices is in the coarse particle fraction. Only for L4 we see not a decrease but an increase for the filtered sample, which we assume to be due to the low concentration. When analyzing the two different juices of sea buckthorn and black currant, we observe that in both cases, the fraction of INP larger than $0.2 \mu \mathrm{m}$ is greater in the juices marked with an $a$. This leads to the assumption that size distributions of INP are not similar within a species or that possible differences in the juice preparation affect the INP sizes. Due to the small size of the filtered INP we assume those to be in the macromolecular size range $\left(10^{-5}\right.$ and $\left.10^{-3} \mathrm{~mm}\right)$. Such small ice nucleating particles have already been found in birch pollen washing water $[51,62,71]$ and are referred to as INM. Such small INM could be important in atmospheric processes, due to the long atmospheric lifespan of particles in such a small size range (up to several days depending on the altitude for particle in the size range of $0.2 \mu \mathrm{m}$ and smaller, (e.g., [4])). Furthermore, these INM could be adsorbed by other particles (e.g., dust particles from soils, [72]), altering ice nucleation properties of a former non-active or less active particle. Small amounts of organic and biological material have already been shown to be capable of increasing the INA of soil and dust [73-75]. Due to their possible role in atmospheric processes it is important to conduct further studies on the release of these small INM from plant materials.

All samples were analyzed with cooling rates between 10 and $20 \mathrm{~K} / \mathrm{min}$. These cooling rates are rather high compared to atmospheric processes. In case some of our samples exhibit time dependent mechanisms, our fast cooling rates could lead to an underestimation of INA. The dependence on time of heterogeneous ice nucleation is not fully understood and seems to be highly impacted by the mechanisms involved [76,77]. Several studies have been done on this, however, most in respect to mineral dust. Few studies indicate importance of the cooling rate [78,79]. However, this behavior is not confirmed by many other studies done on this field [80,81]. Wright et al. included biological material and suggest that cooling rate or residence time only play a minor role in heterogeneous ice nucleation in immersion mode [82].

The origin of biological INP stems from the evolutionary pressure on plants in cold regions. Those plants experiencing cold stress on a regular basis were forced to develop coping mechanisms in order to survive. Freezing of water is challenging for living cells since it leads to ice crystal formation, as well as deformation and dehydration of cells [66]. Intracellular freezing is typically lethal for plants [83-85], many plants therefore developed coping mechanisms to ensure their survival under 
cold conditions [28]. One strategy to avoid cell damage is the controlled ice formation in extracellular spaces, causing dehydration of the cell and inhibiting intracellular freezing $[66,84]$. This behavior is not just dependent on the species, but also on the analyzed tissue $[57,86]$. For most of the analyzed unfiltered plant materials onset, temperatures ranged between $-12.5^{\circ} \mathrm{C}\left(\mathrm{J} 4\right.$, cranberry) and $-25.3^{\circ} \mathrm{C}$ (J2, blueberry) (only E2, rowanberry exhibited a lower freezing temperature: $-29.4^{\circ} \mathrm{C}$ ). Given a high enough concentration of the INM, their mean freezing temperature should be close to the onset temperature. These temperatures are well in line with the reported and highly concentrated plant pollen INM by Pummer et al. [51]. Further, we found that plant materials deriving from different plants of the same species often exhibit similarities in their freezing behavior; however, this was not true for all samples (e.g., leaves of sea buckthorn do not behave like juice and dried berries). The freezing behavior of different species can often be clearly distinguished. Differences of the INP can be of chemical nature, due to a variation in size and structure of the responsible active sites, or based on the remaining chemical composition. As we found a stepwise curve progression for the freezing assays of many samples, it is likely that they consist of different INP or contain active aggregates of different sizes. Brush et al. [49] showed that the ice nucleation active material from winter rye has a complex composition of proteins, carbohydrates, and phospholipids. Small changes in one component could lead to changes in the freezing behavior.

Freezing point depression, which is due to contained small sugars and ions, shifts the freezing point to lower temperatures and consequently leads to a stronger impact of single droplets freezing homogeneously. In summary, it can lead to an MFT below ultrapure water, even though heterogeneous freezing events are present. Freezing point depression is a widely used cold hardiness mechanism of plants [66]. Plants often produce specific substances such as small sugars or in some cases even special antifreeze proteins $[87,88]$. The concentration of those molecules can be highly dependent on the analyzed cell type as well as the season of harvesting [89]. These properties can affect the presented MFT values.

The commercially available juices were all treated with high temperature to prevent microbial spoilage. Muttersaft juices are typically treated with temperatures (to prevent microbial spoilage) as low as possible. However, in the case of elderberry, heat treatment needs to be above $80{ }^{\circ} \mathrm{C}$ to destroy toxic components of the juice [90]. In principle, such heat treatment could have inactivated biological INP [40,51]. Therefore this treatment could have a negative effect on the INA of our samples. However, not all biological INP are affected by heat. Materials from birch trees e.g., have been shown to be resistant towards heat treatment up to at least $100{ }^{\circ} \mathrm{C}[51,91]$. Further it should be noted that the urea treatment can lead to a shift in $\mathrm{pH}$ value, as it can increase the $\mathrm{pH}$ value of aqueous systems and influences the dissociation of weak acids [92]. The $\mathrm{pH}$ can influence the INA [25,93].

To our knowledge there are only a couple of other studies that have addressed the ice nucleation activity of the berries presented in this article. The ice nucleation activity of the sea buckthorn berries was investigated by Lundheim and Wahlberg [56]. They found the freezing temperature of different phenotypes to range between -15.1 and $-6.1{ }^{\circ} \mathrm{C}$ (see Table A1). Our sea buckthorn juice froze at $-18.5^{\circ} \mathrm{C}$, which is slightly below this temperature range. However, Lundheim and Wahlberg [56] used $20 \mu \mathrm{L}$ droplets, which are five orders of magnitude larger than the ones we examine with our setup. The freezing temperature range measured with our setup would be shifted towards higher temperatures if we would use the same droplet size as Lundheim and Wahlberg [56]. Our results for blueberry do not match those found by Kishimoto et al. [57]. While we found a mean freezing temperature of only $-36.5{ }^{\circ} \mathrm{C}$, Kishimoto et al. [57] state a freezing temperature of $-7.2{ }^{\circ} \mathrm{C}$ (see Table A1). Kishimoto et al. [57] worked with $500 \mu \mathrm{L}$ droplets. Within each droplet they immersed half a fruit. Again these huge differences in methodology make results hard to compare. 
The strong effect of subtilisin on sea buckthorn and black currant juice indicates the importance of proteinaceous compounds in their INA. Jann et al. [55] postulated that the INP contained in sea buckthorn can pass through a $0.45 \mu \mathrm{m}$ filter and consist of an aggregate that contains a protein. Our results support these observations and show that the situation is similar for black currant. Urea however had a much smaller effect on black currant than on sea buckthorn, showing that black currant is less sensitive towards denaturating agents. The reduced effect of subtilisin on black currant in the presence of urea can be explained by the reduced activity of subtilisin due to the urea. With an urea concentration of 7.3, the activity of subtilisin is reduced to approx. 10\% [70].

Analyzing the oxidation stability of black currant juice towards ozone, we found no changes in the freezing behavior within $12 \mathrm{~h}$ of testing. This indicates that the contained INP are stable towards oxidation. As the found INP are in the submicron size range, they would exhibit a long atmospheric life span.

It should be mentioned that several contaminations can impact our samples. As they are biological samples, it is likely that at least some of them had contact with other biological material like bacteria and fungi, which are ice nucleation active. Especially in the kingdom of bacteria many are known to exhibit INA $[23,94]$. However, bacteria are not known to release their INA into aqueous solutions and freezing temperatures are typically well above the freezing temperatures observed for our samples $[13,23,94]$. To the authors' knowledge, only one paper found secreted molecules of bacteria to be ice nucleation active [95]. Due to their size, whole bacteria should be separated during the $0.2 \mu \mathrm{m}$ filtration. Fungi on the other hand can release their INP into aqueous solutions, but are typically active at much higher temperatures $\left(>-10^{\circ} \mathrm{C}\right)$ than our samples $[41,96]$. Fungal spores can show freezing temperatures in the observed temperature range [43], but are typically in a size larger $0.2 \mu \mathrm{m}$ and therefore also removed by filtration. Furthermore, the juices are pasteurized; therefore microbial spoilage to a larger degree is unlikely in these samples. This means that contributions from microorganisms by themselves, released products or metabolites should be rather limited if present. Particular contaminations as mineral dusts and soots should be separated by filtration alone.

We investigated plants native to boreal regions, which are common in nature. Therefore, these plants cover a rather high amount of ground depending on the region. We showed that a single leaf is able to release $10^{7}$ to $10^{9}$ INP if submersed into water. Therefore the more vegetation covering the land surface, the higher the amount of INP that can be released during rain events. Further investigation is necessary to estimate the amount of INP released into the atmosphere and the amount of INP released into the soil, potentially adding ice nucleation active centers to other particles. INP from plants are not well studied. Even less attention has been given to their possible role in atmospheric processes. Our results suggest that plants in boreal regions are a huge source for INP. With every rain event the plant surface can release INP into the environment and if these INP get airborne, they can influence the local climatic conditions.

\section{Conclusions}

Following the research questions we stated in the introduction, we found that:

(1) Mean freezing temperatures ranged from -18.5 to $-45.6{ }^{\circ} \mathrm{C}$; cumulative nucleus concentrations between -12 and $-34{ }^{\circ} \mathrm{C}$ ranged from $9.7 \times 10^{5}$ to $9.2 \times 10^{9} \mathrm{~cm}^{-3}$. The onset temperatures of most samples match the literature values for plant derived INP well. The authors would like to highlight black currant, which contains potent INP and exhibited the highest concentrations. To the knowledge of the authors, it was not previously known to act as possible source of INP.

(2) All samples were ice nucleation active and contained INP in a size range smaller than $0.2 \mu \mathrm{m}$, which the authors assume to be INM similar to those described in the literature [51,62,71]. Most juices exhibited losses in INA when filtered. The data suggests that these juices also contain INP larger than $0.2 \mu \mathrm{m}$. 
(3) The INA of the analyzed samples covers a wide range of temperatures and INP concentrations. While most samples from different plants of the same type show similarities (e.g., the different sea buckthorn juices and the dried berries), we also see differences between some of these samples (e.g., sea buckthorn leaves). This makes comparisons between the different samples difficult. Proteins seem to play an important role in the INA of black currant and sea buckthorn. However, black currant is relatively stable towards urea, a denaturating agent.

(4) Three of the samples analyzed were whole dried berries and four samples were intact leaves. We were able to extract INP in the submicron size range from these samples aqueously at room temperature, indicating that berries and leaves can release INP into the environment, even if still intact.

Additional studies are necessary to determine the influence of cultivation regions, growing conditions, as well as phenotype and cultivation history on the formation and activity of plant specific INM. Without this data, we cannot link difference in concentrations, type, and efficiency directly and with certainty to the plant species. Further investigations addressing different plant species and samples are essential to predict the extent of distribution of INMs in plants native to the boreal regions. This is especially important to assess a possible impact of ice nucleation plants to local climatic conditions. The boreal regions are covered with flora for a vast part, which could contribute to atmospheric INP concentrations and for ice nucleation active sites on other atmospheric particles. Our data clearly shows that all plants analyzed contain INP not just in the coarse fraction, but also in the submicron size range. This indicates that plants could be an important source for INP which has been overlooked so far.

Author Contributions: L.F. planned and supervised all experiments, was responsible for the ozone treatment and contributed to writing the manuscript. M.B. was responsible for the measurements of the pure and filtered juices. J.B. contributed in supervising the experiments and writing the manuscript. B.F. was responsible for the subtilisin and urea experiments. T.H. contributed to the setup and to writing the manuscript. R.H. helped planning the experiments and contributed to writing the manuscript. H.G. helped in planning, supervision, and execution of the experiments and contributed to writing the paper.

Acknowledgments: The authors would like to thank David G. Schmale III (VirginiaTech) and Gabor Vali (University of Wyoming) for fruitful discussions and their valuable input. Furthermore, the authors would like to thank the FWF (Austrian Science Fund, project no. P 26040) and the FFG (Austrian Research Promotion Agency, project no. 850689) for funding.

Conflicts of Interest: The authors declare no conflict of interest.

\section{Appendix A}

The freezing temperature of different plant materials which are known to show INA, presented in the introduction. The table shows from left to right: the examined plant material, sample mass, the triggered freezing temperature, droplet volume/size for immersion freezing experiments (measuring INA with the INP immersed in a water droplet), and the corresponding citation. We use the word droplet here for a single freezing unit, not every method used for the data in the table below works with droplets, but rather with discrete volume units. The droplet size used to determine the INA of decayed plant leaf litter was not available. This table only includes selected examples for the samples presented in $[25-27,31]$. The definition of freezing temperatures varies and is indicated at the bottom of the table. Differences in methods and droplet sizes render comparisons between temperatures between studies difficult. 
Table A1. The freezing temperature of different plant materials which are known to show INA, presented in the introduction. The table shows from left to right: the examined plant material, sample mass, the triggered freezing temperature, droplet volume/size for immersion freezing experiments (measuring INA with the INP immersed in a water droplet), and the corresponding citation. We use the word droplet here for a single freezing unit, not every method used for the data in the table below works with droplets, but rather with discrete volume units. The droplet size used to determine the INA of decayed plant leaf litter was not available. This table only includes selected examples for the samples presented in $[50,51,53,57]$. The definition of freezing temperatures varies and is indicated at the bottom of the table. Differences in methods and droplet sizes render comparisons between temperatures between studies difficult:

\begin{tabular}{|c|c|c|c|c|}
\hline Plant/Material & Sample Mass & $\begin{array}{l}\text { Freezing } \\
\text { Temperature }\left({ }^{\circ} \mathrm{C}\right)\end{array}$ & Droplet Volume & Citation \\
\hline Prunus tree wood & $5 \mathrm{~cm}$ sections & $-2^{a}$ & $24 \mathrm{~mL}$ & [47] \\
\hline Citrus fruits & A whole fruit per droplet & $-2.5^{\mathrm{a}}$ & $150 \mathrm{~mL}$ & {$[48]$} \\
\hline $\begin{array}{l}\text { Winter rye leaves } \\
\text { (Secale cereale) }\end{array}$ & $0.1 \mathrm{~g}$ leaf tissue per droplet & $-12--5^{b}$ & $4 \mathrm{~mL}$ & [49] \\
\hline Birch pollen I & * & $-12^{c}$ & * & {$[50]$} \\
\hline Birch pollen II & $50 \mathrm{mg} / \mathrm{mL}$ & $-19^{\mathrm{d}}$ & $0.5-4200 \mathrm{pL}$ & [51] \\
\hline Birch pollen washing water & $\begin{array}{l}\text { Aqueous extract of approx. } \\
50 \mathrm{mg} / \mathrm{mL} \text { pollen, product shows } \\
\text { approx. } 2.4 \mathrm{wt} \% \text { residue }\end{array}$ & $-18^{\mathrm{d}}$ & $0.5-4200 \mathrm{pL}$ & [51] \\
\hline Birch oil & * & $-10^{\mathrm{e}}$ & * & {$[53]$} \\
\hline Pine pollen I & * & $-12^{c}$ & * & {$[50]$} \\
\hline Pine pollen II & $50 \mathrm{mg} / \mathrm{mL}$ & $-20^{d}$ & $0.5-4200 \mathrm{pL}$ & {$[51]$} \\
\hline Pine pollen washing water & $\begin{array}{l}\text { Aqueous extract of approx. } \\
50 \mathrm{mg} / \mathrm{mL} \text { pollen, product shows } \\
\text { approx. } 2.4 \mathrm{wt} \% \text { residue }\end{array}$ & $-21^{\mathrm{d}}$ & $0.5-4200 \mathrm{pL}$ & {$[51]$} \\
\hline Pine oil & * & $-12--9^{e}$ & * & {$[53]$} \\
\hline Decayed leaf litter & 5-100 mg per test dispersed in air & $-24--4^{f}$ & $\mathrm{~N} / \mathrm{A}$ & {$[54]$} \\
\hline $\begin{array}{l}\text { Ripe sea buckthorn } \\
\text { berry juice }\end{array}$ & Tested pure & $-7.9--7.3^{\mathrm{d}}$ & $10 \mu \mathrm{L}$ & {$[55]$} \\
\hline $\begin{array}{l}\text { Centrifuged sea buckthorn } \\
\text { juice from ripe berries of } \\
\text { different origins }\end{array}$ & Pure centrifuged filtered juice & $-15.1--6.1^{\mathrm{a}}$ & $20 \mu \mathrm{L}$ & {$[56]$} \\
\hline Blueberry stem & $7.5 \mathrm{~mm}$ long increments per droplet & $-2.3^{d}$ & $0.5 \mathrm{~mL}$ & {$[57]$} \\
\hline Blueberry fruits & $\begin{array}{l}\text { A whole organ or half cut organ } \\
\text { (to fit the tube) per droplet }\end{array}$ & $-7.2^{\mathrm{d}}$ & $0.5 \mathrm{~mL}$ & [57] \\
\hline
\end{tabular}

*: Used for measurements were methods working with condensation/deposition freezing, where water condenses/freezes directly on the IN. Droplet volume and sample concentration are not available; a: Mean temperature at which ice nucleation occurred; b: Whole freezing range; c: Temperature at which a mean freezing efficiency of $50 \%$ is reached; d: T50 Temperature at which $50 \%$ of the droplets are frozen (median freezing temperature); e: Temperature of ice nucleation, not further defined; f: Extracted data from available freezing nucleus spectra.

\section{References}

1. Cantrell, W.; Heymsfield, A. Production of ice in tropospheric clouds: A review. BAMS 2005, 86, $795-807$. [CrossRef]

2. Hegg, D.A.; Baker, M.B. Nucleation in the atmosphere. Rep. Prog. Phys. 2009, 72, 21. [CrossRef]

3. Murray, B.J.; Broadley, S.L.; Wilson, T.W.; Bull, S.J.; Wills, R.H.; Christenson, H.K.; Murray, E.J. Kinetics of the homogeneous freezing of water. Phys. Chem. Chem. Phys. 2010, 12, 10380-10387. [CrossRef] [PubMed]

4. Pruppbacher, H.R.; Klett, J.D. Microphysics of Clouds and Precipitation, 2nd ed.; Kluwer Acedemic Publishers: Dordrecht, The Netherlands, 1997.

5. Koop, T.; Luo, B.; Tsias, A.; Peter, T. Water activity as the determinant for homogeneous ice nucleation in aqueous solutions. Nature 2000, 406, 611-614. [CrossRef] [PubMed] 
6. Vali, G.; DeMott, P.J.; Möhler, O.; Whale, T.F. Technical Note: A proposal for ice nucleation terminology. Atmos. Chem. Phys. 2015, 15, 10263-10270. [CrossRef]

7. Mishchenko, M.I.; Rossow, W.B.; Macke, A.; Lacis, A.A. Sensitivity of cirrus cloud albedo, bidirectional, reflectance and optical thickness retrieval accuracy to ice particle shape. J. Geophys. Res. 1996, 101, 16973-16985. [CrossRef]

8. Baker, M.B. Cloud microphysics and climate. Science 1997, 276, 1072-1078. [CrossRef]

9. Lohmann, U. A glaciation indirect aerosol effect caused by soot aerosols. Geophys. Res. Lett. 2002, $29,11$. [CrossRef]

10. Forster, V.P.; Ramaswamy, P.; Artaxo, T.; Berntsen, R.; Betts, R.; Fahey, D.W.; Haywood, J.; Lean, J.; Lowe, D.C.; Myhre, G.; et al. Changes in Atmospheric Constituents and in Radiative Forcing. In Climate Change 2007: The Physical Science Basis. Contribution of Working Group I to the Fourth Assessment Report of the Intergovernmental Panel on Climate Change; Solomon, S., Qin, D., Manning, M., Chen, Z., Marquis, M., Averyt, K.B., Tignor, M., Miller, H.L., Eds.; Cambridge University Press: Cambridge, UK; New York, NY, USA, 2007.

11. Möhler, O.; DeMott, P.J.; Vali, G.; Levin, Z. Microbiology and atmospheric processes: The role of biological particles in cloud physics. Biogeosciences 2007, 4, 1059-1071. [CrossRef]

12. Després, V.R.; Huffman, A.J.; Burrows, S.M.; Hoose, C.; Safatov, A.S.; Buryak, G.; Fröhlich-Nowoisky, J.; Elbert, W.; Andreae, M.; Pöschl, U.; et al. Primary biological aerosol particles in the atmosphere: A review. Tellus B Chem. Phys. Meteorol. 2012, 64, 15598. [CrossRef]

13. Murray, B.J.; O'Sullivan, D.; Atkinson, J.D.; Webb, M.E. Ice nucleation by particles immersed in supercooled cloud droplets. Chem. Soc. Rev. 2012, 41, 6519-6554. [CrossRef] [PubMed]

14. DeMott, P.J.; Prenni, A.J.; Liu, X.; Kreidenweis, S.M.; Petters, M.D.; Twohy, C.H.; Richardson, M.S.; Eidhammer, T.; Rodgers, D.C. Predicting global atmospheric ice nuclei distributions and their impacts on climate. Proc. Natl. Acad. Sci. USA 2010, 107, 11217-11222. [CrossRef] [PubMed]

15. Chen, Y.; Kreidenweis, S.M.; McInnes, L.M.; Rogers, D.C.; DeMott, P.J. Single particle analyses of ice nucleating aerosols in the upper troposphere and lower stratosphere. Geophys. Res. Lett. 1998, 25, 1391-1394. [CrossRef]

16. Sesartic, A.; Lohmann, U.; Storelvmo, T. Modelling the impact of fungal spore ice nuclei on clouds and precipitation. Environ. Res. Lett. 2013, 8, 014029. [CrossRef]

17. Sesartic, A.; Lohmann, U.; Storelvmo, T. Bacteria in the ECHAM5-HAM global climate model. Atmos. Chem. Phys. 2012, 12, 8645-8661. [CrossRef]

18. Hoose, C.; Kristjánsson, J.E.; Burrows, S.M. How important is biological ice nucleation in clouds on a global scale? Environ. Res. Lett. 2010, 5, 024009. [CrossRef]

19. Burrows, S.M.; Hoose, C.; Pöschl, U.; Lawrence, M.G. Ice nuclei in marine air: Biogenic particles or dust? Atmos. Chem. Phys. 2013, 13, 245-267. [CrossRef]

20. Pöschl, U.; Martin, S.T.; Sinha, B.; Chen, Q.; Gunthe, S.S.; Huffman, J.A.; Borrmann, S.; Farmer, D.K.; Garland, R.M.; Helas, G.; et al. Rainforest Aerosols as Biogenic Nuclei of Clouds and Precipitation in the Amazon. Science 2010, 329, 1513-1516. [CrossRef] [PubMed]

21. Kohn, M. Laboratory and Field Measurements of Immersion Freezing Utilizing a Newly Developed Cloud Chamber. Ph.D. Thesis, ETH Zürich, Zürich, Switzerland, 2016.

22. Huffman, J.A.; Prenni, A.J.; Demott, P.J.; Pöhlker, C.; Mason, R.H.; Robinson, N.H.; Fröhlich-Nowoisky, J.; Tobo, Y.; Després, V.R.; Garcia, E.; et al. High concentrations of biological aerosol particles and ice nuclei during and after rain. Atmos. Chem. Phys. 2013, 13, 6151-6164. [CrossRef]

23. Maki, L.R.; Galyan, E.L.; Chang-Chien, M.M.; Caldwell, D.R. Ice Nucleation Induced by Pseudomonas syringae. Appl. Environ. Microbiol. 1974, 28, 456-459.

24. Morris, C.E.; Sands, D.C.; Bardin, M.; Jaenicke, R.; Vogel, B.; Leyronas, C.; Ariya, P.A.; Psenner, R. Microbiology and atmospheric processes: Research challenges concerning the impact of airborne micro-organisms on the atmosphere and climate. Biogeosciences 2011, 8, 17-25. [CrossRef]

25. Attard, E.; Yang, H.; Delort, A.M.; Amato, P.; Pöschl, U.; Glaux, C.; Koop, T.; Morris, C.E. Effects of atmospheric conditions on ice nucleation activity of Pseudomonas. Atmos. Chem. Phys. 2012, 12, 10667-10677. [CrossRef]

26. Stephens, E.R. Chemistry of atmospheric oxidants. J. Air Pollut. Control Assoc. 1969, 19, 181-185. [CrossRef]

27. Fitzner, M.; Sosso, G.C.; Cox, S.J.; Michaelides, A. The Many Faces of Heterogeneous Ice Nucleation: Interplay between Surface Morphology and Hydrophobicity. J. Am. Chem. Soc. 2015, 137, 13658-13669. [CrossRef] [PubMed] 
28. Zachariassen, K.E.; Kristiansen, E. Ice nucleation and antinucleation in nature. Cryobiology 2000, 41, $257-279$. [CrossRef] [PubMed]

29. Kajava, A.V.; Lindow, S.E. A model of the three-dimensional structure of ice nucleation proteins. J. Mol. Biol. 1993, 232, 709-717. [CrossRef] [PubMed]

30. Warren, G.; Wolber, P. Molecular aspects of microbial ice nucleation. Mol. Microbiol. 1991, 5, $239-243$. [CrossRef] [PubMed]

31. Schmid, D.; Pridmore, D.; Capitani, G.; Battistutta, R.; Neeser, J.R.; Jann, A. Molecular organisation of the ice nucleation protein InaV from Pseudomonas syringae. FEBS Lett. 1997, 414, 590-594. [CrossRef]

32. Garnham, C.P.; Campbell, R.L.; Walker, V.K.; Davies, P.L. Novel dimeric $\beta$-helical model of an ice nucleation protein with bridged active sites. BMC Struct. Biol. 2011, 11, 36. [CrossRef]

33. Pratt, K.A.; Demottm, P.J.; French, J.R.; Wang, Z.; Westphal, D.L.; Heymsfield, A.J.; Twohy, C.H.; Prenni, A.J.; Prather, K.A. In situ detection of biological particles in cloud ice-crystals. Nat. Geosci. 2009, 2, 398-401. [CrossRef]

34. Baustian, K.J.; Cziczo, D.J.; Wise, M.E.; Pratt, K.A.; Kulkarni, G.; Hallar, A.G.; Tolbert, M.A. Importance of aerosol composition, mixing state, and morphology for heterogeneous ice nucleation: A combined field and laboratory approach. J. Geophys. Res. Atmos. 2012, 117, D06217. [CrossRef]

35. Möhler, O.; Benz, S.; Saathoff, H.; Schnaiter, M.; Wagner, R.; Schneider, J.; Walter, S.; Ebert, V.; Wagner, S. The effect of organic coating on the heterogeneous ice nucleation efficiency of mineral dust aerosols. Environ. Res. Lett. 2008, 3, 025007. [CrossRef]

36. Sands, D.C.; Langham, V.E.; Scharen, A.L.; de Smet, C. The association between bacteria and rain and possible resultant meteorological implications. Idojaras 1982, 86, 148-152.

37. Morris, C.E.; Conen, F.; Huffman, A.J.; Phillips, V.; Pöschl, U.; Sands, D.C. Bioprecipitation: A feedback cycle linking Earth history, ecosystem dynamics and land use through biological ice nucleators in the atmosphere. Glob. Chang. Biol. 2014, 20, 341-351. [CrossRef] [PubMed]

38. Lindow, S.E.; Arny, D.C.; Upper, C.D. Bacterial Ice Nucleation: A Factor in Frost Injury to Plants. Plant Physiol. 1982, 70, 1084-1089. [CrossRef] [PubMed]

39. Wolber, P.; Deininger, C.; Southworth, M.; Vandekerckhove, J.; van Montagu, M.; Warren, G. Identification and purification of a bacterial ice-nucleation protein. Proc. Natl. Acad. Sci. USA 1986, 83, 7256-7260. [CrossRef]

40. Pouleur, S.; Richard, C.; Martin, J.G.; Antoun, H. Ice Nucleation Activity in Fusarium-Acuminatum and Fusarium-Avenaceum. Appl. Environ. Microbiol. 1992, 58, 2960-2964.

41. Fröhlich-Nowoisky, J.; Hill, T.C.J.; Pummer, B.G.; Yordanova, P.; Franc, G.D.; Pöschl, U. Ice nucleation activity in the widespread soil fungus Mortierella alpina. Biogeosciences 2015, 12, 1057-1071. [CrossRef]

42. Iannone, R.; Chernoff, D.I.; Pringle, A.; Martin, S.T.; Bertram, A.K. The ice nucleation ability of one of the most abundant types of fungal spores found in the atmosphere. Atmos. Chem. Phys. 2011, 11, 1191-1201. [CrossRef]

43. Haga, D.I.; Iannone, R.; Wheeler, M.J.; Mason, R.; Polishchuk, E.A.; Fetch, T.; van der Kamp, B.J.; McKendry, L.G.; Bertram, A.K. Ice nucleation properties of rust and bunt fungal spores and their transport to high altitudes, where they can cause heterogeneous freezing. J. Geophys. Res. Atmos. 2013, 118, 7260-7272. [CrossRef]

44. Weber, C.F. Polytrichum commune spores nucleate ice and associated microorganisms increase the temperature of ice nucleation activity onset. Aerobiologia 2016, 32, 353-361. [CrossRef]

45. Kieft, T.L. Ice nucleation activity in lichens. Appl. Environ. Microbiol. 1988, 54, 1678-1681. [PubMed]

46. Jaenicke, R. Abundance of cellular material and proteins in the atmosphere. Science 2005, 308, 73. [CrossRef] [PubMed]

47. Gross, D.C.; Proebsting, E.L.; Maccrindle-zimmerman, H. Development, Distribution, and Characteristics of Intrinsic, Nonbacterial Ice Nuclei in Prunus Wood. Plant Physiol. 1988, 88, 915-922. [CrossRef] [PubMed]

48. Constantinidou, H.A.; Menkissoglu, O. Characteristics and importance of heterogeneous ice nuclei associated with citrus fruits. J. Exp. Bot. 1992, 43, 585-591. [CrossRef]

49. Brush, R.A.; Griffith, M.; Mlynarz, A. Characterization and Quantification of Intrinsic Ice Nucleators in Winter Rye (Secale-Cereale) Leaves. Plant Physiol. 1994, 104, 725-735. [CrossRef] [PubMed]

50. Diehl, K.; Quick, C.; Matthias-Maser, S.; Mitra, S.K.; Jaenicke, R. The ice nucleating ability of pollen Part I: Laboratory studies in deposition and condensation freezing modes. Atmos. Res. 2001, 58, 75-87. [CrossRef] 
51. Pummer, B.G.; Bauer, H.; Bernardi, J.; Bleicher, S.; Grothe, H. Suspendable macromolecules are responsible for ice nucleation activity of birch and conifer pollen. Atmos. Chem. Phys. 2012, 12, 2541-2550. [CrossRef]

52. Macromolecule. Available online: https://www.britannica.com/science/macromolecule (accessed on 16 December 2018).

53. Rosinski, J.; Parungo, F. Terpene-Iodine Compounds as Ice Nuclei. J. Appl. Meteorol. 1966, 5, 119-123. [CrossRef]

54. Schnell, R.C.; Vali, G. Biogenic Ice Nuclei: Part I. Terrestrial and Marine Sources. J. Atmos. Sci. 1976, 33, 1554-1564. [CrossRef]

55. Jann, A.; Lundheim, R.; Niederberger, P.; Richard, M. Increasing Freezing Point of Food with Sea Buckthorn Ice Nucleating Agent. U.S. Patent 5,665,361, 9 September 1997.

56. Lundheim, R.; Wahlberg, K. Ice nucleation in fruit juice from different varieties of sea buckthorn Hippophaë rhamnoides L. Euphytica 1998, 102, 117-124. [CrossRef]

57. Kishimoto, T.; Yamazaki, H.; Saruwatari, A.; Murakawa, H.; Sekozawa, Y.; Kuchitsu, K.; Price, W.S.; Ishikawa, M. High ice nucleation activity located in blueberry stem bark is linked to primary freeze initiation and adaptive freezing behaviour of the bark. AoB Plants 2014, 6, 1-17. [CrossRef] [PubMed]

58. Dreischmeier, K.; Budke, C.; Wiehemeier, L.; Kottke, T.; Koop, T. Boreal pollen contain ice-nucleating as well as ice-binding "antifreeze" polysaccharides. Sci. Rep. 2017, 7, 1-13. [CrossRef] [PubMed]

59. Tong, H.J.; Ouyang, B.; Nikolovski, N.; Lienhard, D.M.; Pope, F.D.; Kalberer, M. A new electrodynamic balance (EDB) design for low-temperature studies: Application to immersion freezing of pollen extract bioaerosols. Atmos. Meas. Tech. 2015, 8, 1183-1195. [CrossRef]

60. Wisniewski, M.; Lindow, S.E.; Ashworth, E.N. Observations of Ice Nucleation and Propagation in Plants Using Infrared Video Thermography. Plant Physiol. 1997, 113, 327-334. [CrossRef] [PubMed]

61. Ashworth, E.N. Xylem development in prunus flower buds and the relationship to deep supercooling. Plant Physiol. 1984, 74, 862-865. [CrossRef] [PubMed]

62. Pummer, B.G.; Budke, C.; Augustin-Bauditz, S.; Niedermeier, D.; Felgitsch, L.; Kampf, C.J.; Huber, R.G.; Liedl, K.R.; Loerting, T.; Moschen, T.; et al. Ice nucleation by water-soluble macromolecules. Atmos. Chem. Phys. 2015, 15, 4077-4091. [CrossRef]

63. Hauptmann, A.; Handle, K.F.; Baloh, P.; Grothe, H.; Loerting, T. Does the emulsification procedure influence freezing and thawing of aqueous droplets? J. Chem. Phys. 2016, 145, 211923. [CrossRef] [PubMed]

64. Vali, G. Quantitative Evaluation of Experimental Results an the Heterogeneous Freezing Nucleation of Supercooled Liquids. J. Atmos. Sci. 1971, 28, 402-409. [CrossRef]

65. Govindarajan, A.G.; Lindow, S.E. Size of bacterial ice-nucleation sites measured in situ by radiation inactivation analysis. Proc. Natl. Acad. Sci. USA 1988, 85, 1334-1338. [CrossRef] [PubMed]

66. Storey, J.M.; Storey, K.B. Cold Hardiness and Freeze Tolerance. In Functional Metabolism: Regulation and Adaptation; Storey, K.B., Ed.; John Wiley \& Sons, Inc.: Hoboken, NJ, USA, 2004; pp. 470-503. [CrossRef]

67. Hedstrom, L. Serine protease mechanism and specificity. Chem. Rev. 2002, 102, 4501-4523. [CrossRef] [PubMed]

68. Wallqvist, A.; Covell, D.G.; Thirumalai, D. Hydrophobic interactions in aqueous urea solutions with implications for the mechanism of protein denaturation. J. Am. Chem. Soc. 1998, 120, 427-428. [CrossRef]

69. Salvi, G.; Rios, P.D.L.; Vendruscolo, M. Effective Interactions between Chaotropic Agents and Proteins. Proteins Struct. Funct. Bioinform. 2005, 499, 492-499. [CrossRef] [PubMed]

70. Guo, Y.; Clark, D.S. Activation of enzymes for nonaqueous biocatalysis by denaturing concentrations of urea. Biochim. Biophys. Acta Protein Struct. Mol. Enzymol. 2001, 1546, 406-411. [CrossRef]

71. O'Sullivan, D.; Murray, B.J.; Ross, J.F.; Whale, T.F.; Price, H.C.; Atkinson, J.D.; Umo, N.S.; Webb, M.E. The relevance of nanoscale biological fragments for ice nucleation in clouds. Sci. Rep. 2015, 5, 8082. [CrossRef]

72. O'Sullivan, D.; Murray, B.J.; Ross, J.F.; Webb, M.E. The adsorption of fungal ice-nucleating proteins on mineral dusts: A terrestrial reservoir of atmospheric ice-nucleating particles. Atmos. Chem. Phys. 2016, 16, 7879-7887. [CrossRef]

73. Conen, F.; Morris, C.E.; Leifeld, J.; Yakutin, M.V.; Alewell, C. Biological residues define the ice nucleation properties of soil dust. Atmos. Chem. Phys. 2011, 11, 9643-9648. [CrossRef]

74. Tobo, Y.; Demott, P.J.; Hill, T.C.J.; Prenni, A.J.; Swoboda-Colberg, N.G.; Franc, G.D.; Kreidenweis, S.M. Organic matter matters for ice nuclei of agricultural soil origin. Atmos. Chem. Phys. 2014, 14, 8521-8531. [CrossRef] 
75. Hill, T.C.J.; Demott, P.J.; Tobo, Y.; Fröhlich-Nowoisky, J.; Moffett, B.F.; Franc, G.D.; Kreidenweis, S.M. Sources of organic ice nucleating particles in soils. Atmos. Chem. Phys. 2016, 16, 7195-7211. [CrossRef]

76. Vali, G. Interpretation of freezing nucleation experiments: Singular and stochastic; Sites and surfaces. Atmos. Chem. Phys. 2014, 14, 5271-5294. [CrossRef]

77. Niedermeier, D.; Shaw, R.A.; Hartmann, S.; Wex, H.; Clauss, T.; Voigtländer, J.; Stratmann, F. Heterogeneous ice nucleation: Exploring the transition from stochastic to singular freezing behavior. Atmos. Chem. Phys. 2011, 11, 8767-8775. [CrossRef]

78. Murray, B.J.; Broadley, S.L.; Wilson, T.W.; Atkinson, J.D.; Wills, R.H. Heterogeneous freezing of water droplets containing kaolinite particles. Atmos. Chem. Phys. 2011, 11, 4191-4207. [CrossRef]

79. Welti, A.; Lüönd, F.; Kanji, Z.A.; Stetzer, O.; Lohmann, U. Time dependence of immersion freezing: An experimental study on size selected kaolinite particles. Atmos. Chem. Phys. 2012, 12, 9893-9907. [CrossRef]

80. Broadley, S.L.; Murray, B.J.; Herbert, R.J.; Atkinson, J.D.; Dobbie, S.; Malkin, T.L.; Condliffe, E.; Neve, L. Immersion mode heterogeneous ice nucleation by an illite rich powder representative of atmospheric mineral dust. Atmos. Chem. Phys. 2012, 12, 287-307. [CrossRef]

81. DeMott, P.J. An Exploratory Study of Ice Nucleation by Soot Aerosols. J. Appl. Meteorol. 1990, 29, $1072-1079$. [CrossRef]

82. Wright, T.P.; Petters, M.D.; Hader, J.D.; Morton, T.; Holder, A.L. Minimal cooling rate dependence of ice nuclei activity in the immersion mode. J. Geophys Res. Atmos 2013, 118, 10535-10543. [CrossRef]

83. Mazur, P. Freezing Injury in Plants. Annu. Rev. Plant Physiol. 1969, 20, 419-448. [CrossRef]

84. Burke, M.J.; Gusta, L.V.; Quamme, H.A.; Weiser, C.J.; Li, P.H. Freezing and Injury in Plants. Annu. Rev. Plant Physiol. 1976, 27, 507-528. [CrossRef]

85. Pearce, R. Plant Freezing and Damage. Ann. Bot. 2001, 87, 417-424. [CrossRef]

86. Ishikawa, M.; Ide, H.; Price, W.S.; Arata, Y.; Nakamura, T.; Kishimoto, T. Freezing Behaviours in Plant Tissues: Visualization using NMR Micro-imaging and Biochemical Regulatory Factors Invovled. In Plant Cold Hardiness: From the Laboratory to the Field; Gusta, L.V., Wisniewski, M., Tanino, K.K., Eds.; CAB International: Wallingford, UK, 2009; pp. 19-28. [CrossRef]

87. Griffith, M.; Ala, P.; Yang, D.S.C.; Hon, W.-C.; Moffatt, B.A. Antifreeze Protein Produced Endogenously in Winter Rye Leaves. Plant Physiol. 1992, 100, 593-596. [CrossRef]

88. Urrutia, M.E.; Duman, J.G.; Knight, C.A. Plant thermal hysteresis proteins. Biochim. Biophys. Acta Protein Struct. Mol. 1992, 1121, 199-206. [CrossRef]

89. Kasuga, J.; Arakawa, K.; Fujikawa, S. High accumulation of soluble sugars in deep supercooling Japanese white birch xylem parenchyma cells. New Phytol. 2007, 174, 569-579. [CrossRef] [PubMed]

90. Pogorzelski, E. Formation of cyanide as a product of decomposition of cyanogenic glucosides in the treatment of elderberry fruit (Sambucus nigra). J. Sci. Food Agric. 1982, 33, 496-498. [CrossRef]

91. Felgitsch, L.; Baloh, P.; Burkart, J.; Mayr, M.; Momken, M.E.; Seifried, T.M.; Winkler, P.; Schmale, D.G., III; Grothe, H. Birch leaves and branches as a source of ice-nucleating macromolecules. Atmos. Chem. Phys. 2018, 18, 16063-16079. [CrossRef]

92. Bull, H.B.; Breese, K.; Ferguson, G.L.; Swenson, C.A. The pH of Urea Solutions. Arch. Biochem. Biophys. 1964, 104, 297-304. [CrossRef]

93. Abdelmonem, A.; Backus, E.H.; Hoffmann, N.; Sánchez, M.A.; Cyran, J.D.; Kiselev, A.; Bonn, M. Surface-charge-induced orientation of interfacial water suppresses heterogeneous ice nucleation on $\alpha$-alumina (0001). Atmos. Chem. Phys. 2017, 17, 7827-7837. [CrossRef]

94. Lindow, S.E.; Arny, D.C.; Upper, C.D. Erwinia herbicola: A Bacterial Ice Nucleus Active in Increasing Frost Injury to Corn. Phytopatology 1977, 68, 523-527. [CrossRef]

95. Failor, K.C.; Schmale, D.G., III; Vinatzer, B.A.; Monteil, C.L. Ice nucleation active bacteria in precipitation are genetically diverse and nucleate ice by employing different mechanisms. ISME J. 2017, 11, 2740-2753. [CrossRef]

96. Du, R.; Du, P.; Lu, Z.; Ren, W.; Liang, Z.; Qin, S.; Li, Z.; Wang, Y.; Fu, P. Evidence for a missing source of efficient ice nuclei. Sci. Rep. 2017, 7, 39673. [CrossRef]

(C) 2019 by the authors. Licensee MDPI, Basel, Switzerland. This article is an open access article distributed under the terms and conditions of the Creative Commons Attribution (CC BY) license (http:/ / creativecommons.org/licenses/by/4.0/). 